\title{
Azolo[1,5-a]pyrimidines and Their Condensed Analogs with Anticoagulant Activity
}

\author{
Konstantin V. Savateev ${ }^{1 *}$, Victor V. Fedotov ${ }^{1}$, Vladimir L. Rusinov ${ }^{1}$, Svetlana K. Kotovskaya ${ }^{1}$, Alexandr A. Spasov ${ }^{2}$, \\ Aida F. Kucheryavenko², Pavel M. Vasiliev², Vadim A. Kosolapov², Victor S. Sirotenko², Kseniya A. Gaidukova ${ }^{2}$, \\ Georgiy M. Uskov²
}
1 Department of organic and biomolecular chemistry, Ural Federal University named after the First President of Russia B.N. Eltsin, Mira st. 19, Yekaterinburg, 620002, Russian Federation;
2 bDepartment of Pharmacology and Bioinformatics, Volgograd State Medical University, Pavshikh Bortsov Sq. 1,Volgograd, 400131, Russian Federation
* Correspondence: i-krafttt@yandex.ru;

\begin{abstract}
Hypercytokinemia, or cytokine storm, is one of the severe complications of viral and bacterial infections, involving the release of abnormal amounts of cytokines, resulting in a massive inflammatory response. Cytokine storm is associated with COVID-19 and sepsis high mortality rate by developing epithelial dysfunction and coagulopathy, leading to thromboembolism and multiple organ dysfunction syndrome. The anticoagulant therapy is an important tactic to prevent thrombosis in sepsis and COVID-19, but recent data show the incompatibility of modern direct oral anticoagulants and antiviral agents. It seems relevant to develop dual-action drugs with antiviral and anticoagulant properties. At the same time it was shown that azolo[1,5-a]pyrimidines are heterocycles with a broad spectrum of antiviral activity. We have synthesized a new family of azolo[1,5a]pyrimidines and their condensed polycyclic analogs by cyclocondensation reactions and direct $\mathrm{CH}$-functionalization and studied their anticoagulant properties. Five compounds among 1,2,4-triazolo[1,5-a]pyrimidin-7-ones and 5-alkyl-1,3,4-thiadiazolo[3,2-a]purin-8-ones demonstrated higher anticoagulant activity than the reference drug, dabigatran etexilate. Antithrombin activity of lead compounds was confirmed using lipopolysaccharide (LPS) treated blood to mimic conditions of cytokine release syndrome. The studied compounds affected only the thrombin time value, reliably increasing it 6.5-15.2 times as compared to LPS-treated blood.
\end{abstract}

Keywords: azolo[1,5-a]pyrimidines; benzo[4,5]imidazo[1,2-a][1,2,3]triazolo[4,5-e]pyrimidines; nitrocompounds; anticoagulant; cytokine storm.

\section{Introduction}

Hypercytokinemia, or cytokine storm, is one of the severe complications of viral and bacterial infections, including COVID-19 caused by SARS-CoV-2. Activation of immune cells leads to damage of the endothelium of pulmonary vessels and, consequently, disrupts its protective functions, namely decreases the release of nitric oxide and $\mathrm{PGI}_{2}$, which suppress the activation and adhesion of leukocytes. Thrombin generation leads to the formation of fibrin, activation of platelets and endothelial cells through PAR-1 receptors, increased production of von Willebrand factor (VWF) and aggravates inflammation, causing activation of P-selectin, activates leukocytes and smooth endothelial muscles, releasing multiple cytokines [1]. As a result, systemic endothelial dysfunction and sepsis-induced coagulopathy are associated with an increased risk of death, due to venous (about $70 \%$ of patients in critical condition) or arterial thromboembolic events, much less often to hemorrhagic complications [2-4]. Disseminated intravascular coagulation (DIC) and systemic disorders lead to multiple organ failure, a characteristic of severe COVID-19. Anticoagulants hold one of the central positions among the means to prevent thrombosis in these conditions [5]. However, the use of currently available direct anticoagulants in COVID-19 is limited due to safety issues [6]. Therefore, the search and development of 
novel pharmacological agents that reduce the thrombogenic potential of blood via coagulation and platelet activation management remain an important and urgent task. Drugs that combine anticoagulant, antiviral and/or antibacterial activity to reduce the risk of sepsis-induced coagulopathy and arterial thromboembolism are of special interest. At the same time, heterocyclic derivatives of the azoloazine nature and their condensed derivatives are known for their broad range of biological activity [7]. Especially, it was shown that these compounds have a pronounced protective effect against septic shock and influenza virus in vivo $[7,8]$. Consequently, we consider the study of azoloazine heterocycles as potential anticoagulant agents for the treatment of cytokine storm and, in particular, DIC promising and very relevant in the modern epidemic situation. Therefore, in the present paper, we propose a data on the synthesis of the new derivatives of azoloazine series: 6ethoxycarbonyl- and 6-nitro-azolo[1,5-a]pyrimidines and 3-nitrobenzimidazo[1,2-a]pyrimidines and their structural analogs, polycyclic thiadiazolo[3,2-a]purines and benzimidazo[1,2-a]-1,2,3-triazolo[4,5-e]pyrimidines. The obtained compounds have been evaluated for their anticoagulant effect by in vitro/in vivo experiments. Additionally, the most important structural fragments responsible for this type of activity were identified based on iterative neural network pharmacophore analysis.

\section{Results}

\subsection{Chemistry}

It was shown previously that nitrogroup plays essential role in the azoloazine series for pronounced antiviral/antiseptic effect [7]. Considering this and structural similarity between nitro and ethoxycarbonyl fragments we synthesized a series of a new azolo[1,5a]pyrimidines $\mathbf{3 a - 1}$ by the reaction of commercially available aminoazoles $\mathbf{1 a}-\mathbf{h}$ and carbonyl-containing synthetic equivalents e.g. diethyl ethoxymethylenemalonate 2a and ethyl ethoxymethylenenitroacetate $\mathbf{2 b}$ (Scheme 1 ).

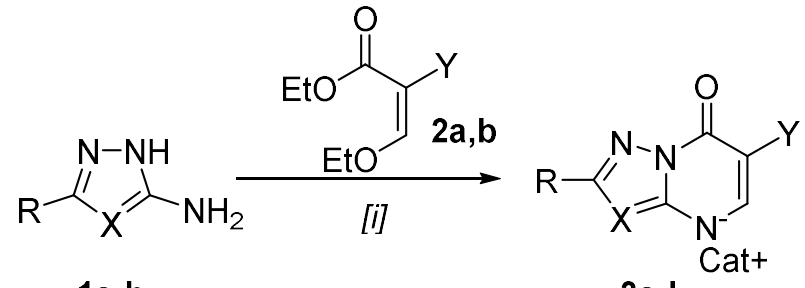

1a-h $3 a-1$

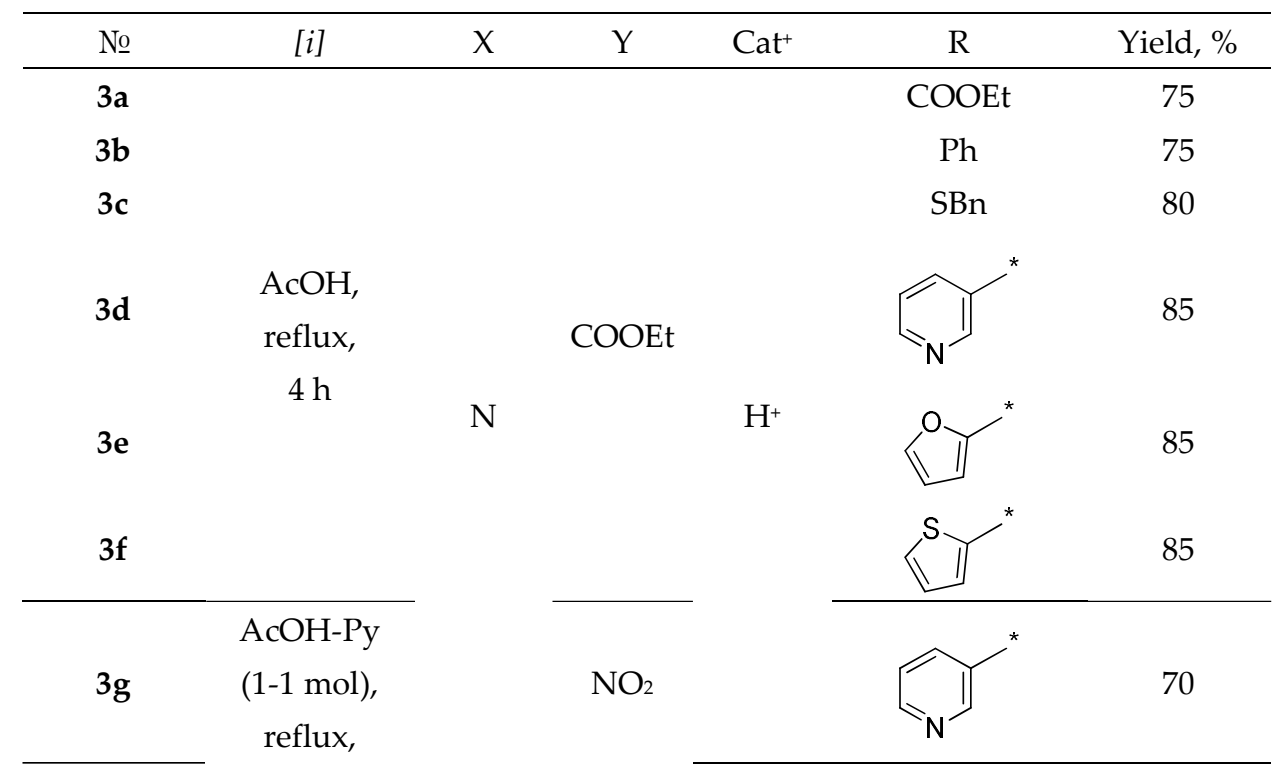




$3 \mathbf{h} 6 \mathrm{~h}$

Scheme 1. Synthesis of azolo[1,5-a]pyrimidin-7-ones 3a-1

A cyclocondensation of 3-R-5-amino-1,2,4-triazoles 1a-f with diethyl ethoxymethylenemalonate 2a was carried out at the reflux for 4 hours in glacial acetic acid to form the target 6-ethoxycarbonyltriazolo[1,5-a]pyrimidines 3a-f with excellent yields (75-85\%). On the contrary, the condensation of aminoazoles 1a-h with ethyl ethoxymethylenenitroacetate $\mathbf{2} \mathbf{b}$ in similar condition leads to an acylation products of the starting aminoazoles 1ah. At the same time, desired 6-nitroazolo[1,5-a]pyrimidines 3g-1 were obtained with good yields (60-75\%) when using an equimolar pyridine/acetic acid mixture as solvent. It should be noted, that the corresponding products $3 \mathrm{~h}-\mathbf{l}$ were isolated as pyridinium salts except for compound $3 \mathrm{~g}$. It can be explained by the fact that 6 -nitroazolo[1,5-a]pyrimidines are a strong $\mathrm{NH}$-acids due to electron-withdrawing effect of the nitrogroup on the heterocyclic system, while 2-(pyridin-3-yl)-6-nitrotriazolo[1,5-a]pyrimidine $3 \mathrm{~g}$ can exist as a zwitterion with minus charge at pyrimidine-nitrogen and plus charge at pyridine-nitrogen atom.

An analog of azolopyrimidine $3 \mathbf{k}$ with C5-methyl substituent was obtained by twostep procedure. Initially, condensation of aminoazole $1 \mathbf{e}$ with ethyl acetoacetate was carried out to form triazolopyrimidine 4 with good yield (80\%). The following nitration of derivative 4 by the act of nitric and sulfuric acids mixture led to target dinitrotriazolo[1,5a]pyrimidine $3 \mathrm{~m}$ (Scheme 2 ).

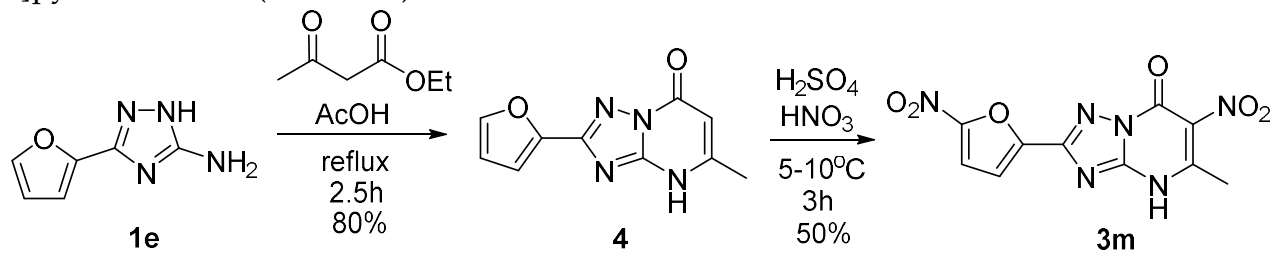

Scheme 2. Two-step synthesis of dinitrotriazolopyrimidin-7-one $3 \mathrm{~m}$

Different salts of 2-(fur-2-yl)-6-nitrotriazolo[1,5-a]pyrimidin-7-one 3n-q were obtained on the basis of heterocycle $3 i$ to establish the effect of the cation on anticoagulant activity and improve solubility in aqueous media (Scheme 3).<smiles>O=c1c([N+](=O)[O-])c[nH]c2nc(-c3ccco3)nn12</smiles>

$3 \mathbf{i}$<smiles>C1=CCC1</smiles><smiles></smiles>

\begin{tabular}{cccc} 
№ & {$[i]$} & $\mathrm{Cat}^{+}$ & Yield, \% \\
\hline 3n & $\mathrm{NaOH}, \mathrm{H} 2 \mathrm{O}$, reflux, & $\mathrm{Na}^{+}$ & 60 \\
3o & $\begin{array}{c}10 \text { min } \\
\mathrm{NH}_{4} \mathrm{OH}, \text { reflux, }\end{array}$ & $\mathrm{H}_{4} \mathrm{~N}^{+}$ & 65
\end{tabular}


1. $\mathrm{HCl}_{\text {conc., }} \mathrm{H}_{2} \mathrm{O}$

$3 p$

2. Morpholine, $\mathrm{H}_{2} \mathrm{O}$, reflux,

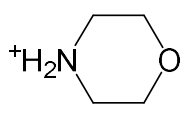

65

$10 \mathrm{~min}$

1. $\mathrm{HCl}_{\text {conc., }} \mathrm{H}_{2} \mathrm{O}$

$3 q$

2. L-arginine, $\mathrm{H}_{2} \mathrm{O}$, reflux,

$10 \mathrm{~min}$<smiles>NC(=[NH2+])NCCC[C@H](N)C(=O)O</smiles>

70

Scheme 3. A series of water-soluble heterocycles $3 n-q$

In addition to azolo[1,5-a]pyrimidines 3a-q some condensed polycyclic systems were obtained. First of all, 5-alkylthiadiazolo[3,2-a]purines 6a-c were synthesized on the basis of 5-alkylamino-6-nitrothiadiazolo[3,2-a]pyrimidin-7-ones 5a-c by one-pot reduction of the nitrogroup and subsequent annulation of the imidazole fragment in $\mathrm{Fe}-\mathrm{AcOH}-$ $\mathrm{HC}(\mathrm{OEt})_{3}$ system (Scheme 4).<smiles>[R]Nc1nc2scnn2c(=O)c1[N+](=O)[O-]</smiles>

5a-c

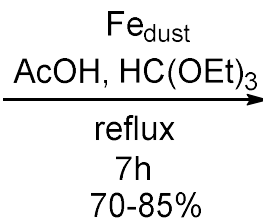

$70-85 \%$<smiles>[R]n1cnc2c(=O)n3ncsc3nc21</smiles>

6a-c $\quad \mathrm{R}$

$$
\left.\mathrm{R}=\mathrm{a})\left(\mathrm{CH}_{2}\right)_{2} \mathrm{Ph}-4-\mathrm{OH}, \mathrm{b}\right) \text { cyclo-Pr, c) }\left(\mathrm{CH}_{2}\right)_{4} \mathrm{OCH}(\mathrm{OEt})_{2}
$$

Scheme 4. One-pot method for 5-alkylthiadiazolo[3,2-a]purin-8-ones 6a-c

3-Nitrobenzimidazo[1,2-a]pyrimidin-4(10H)-one $\mathbf{8}$ as structural analog of corresponding 6-nitroazolopyrimidine $3 \mathbf{n}$ was obtained by the similar procedure starting from aminobenzimidazole 7 (Scheme 5).

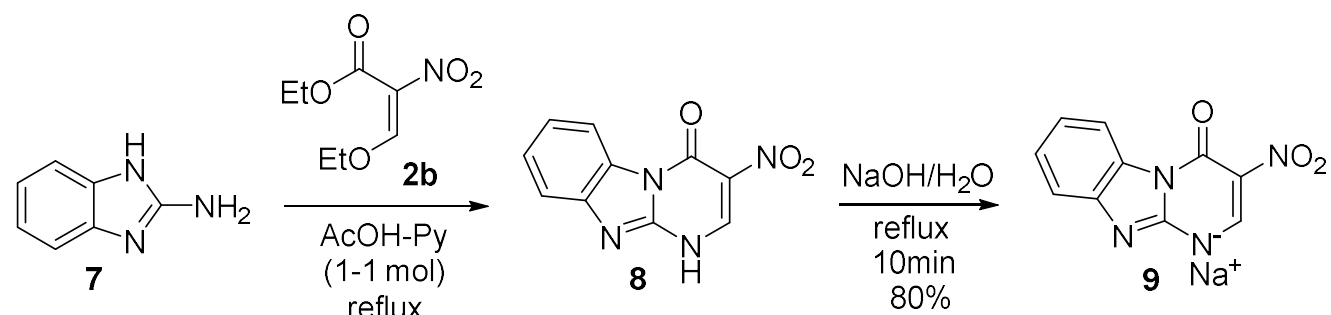

Scheme 5. Synthesis of 3-nitrobenzimidazopyrimidinesodium salt 9

Finally, a pathway to C4-modified benzo[4,5]imidazo[1,2-a][1,2,3]triazolo[4,5e]pyrimidines 13a-e, 14a was revealed by the means of $\mathrm{CH}$-functionalization. It was found, that the reaction of benzimidazoazapurines $10 \mathbf{a}, \mathbf{b}$ with $\mathrm{C}$-nucleophiles in $\mathrm{CF}_{3} \mathrm{COOH}$ proceeded smoothly with the formation of stable $\sigma \mathrm{H}$-adducts $11 \mathbf{a}-\mathbf{e}, \mathbf{1 2 b}$ as trifluoroacetates. 


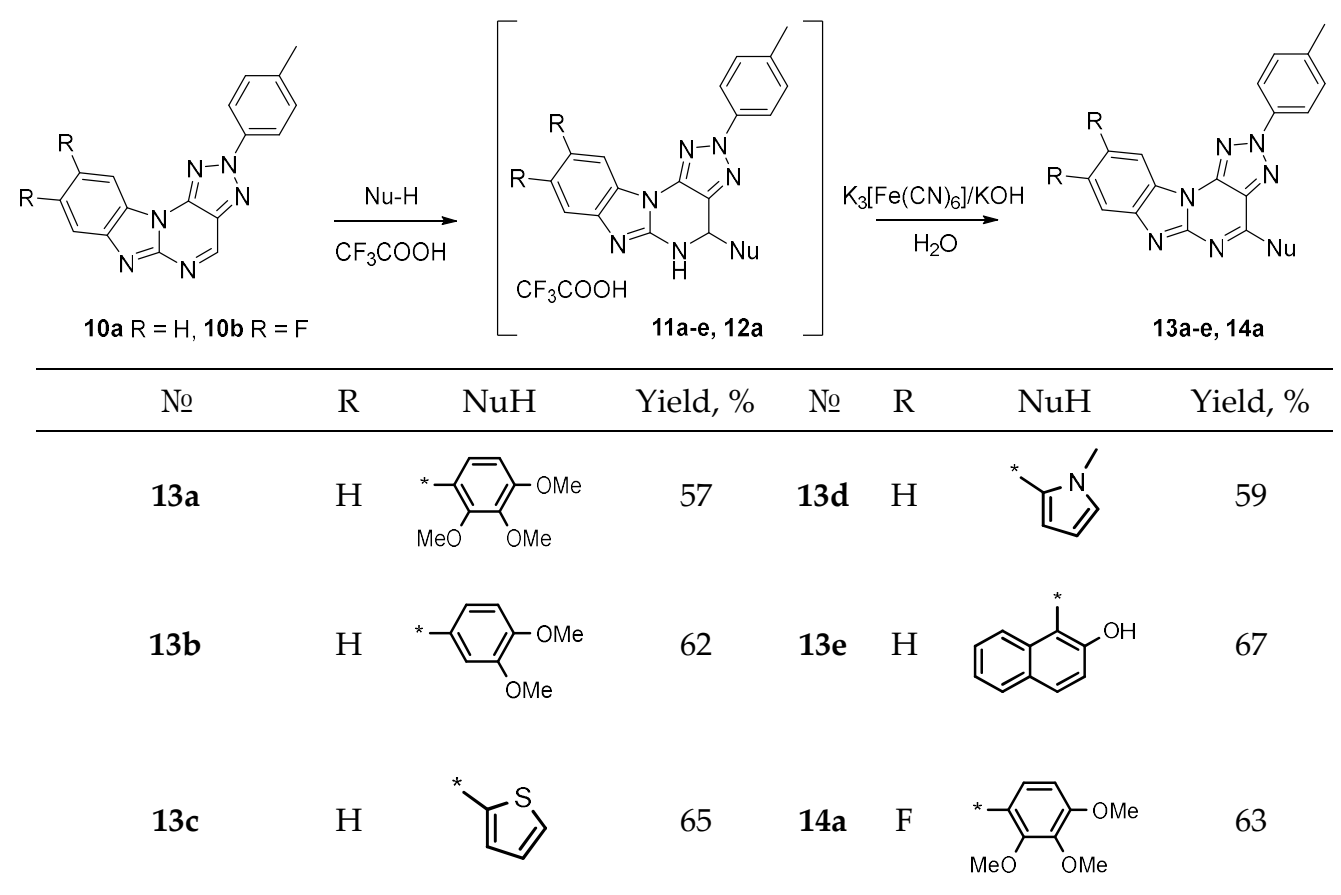

Scheme 6. CH-functionalizationof the benzimidazoazapurines 10a, b

The following oxidation by $\mathrm{K}_{3}\left[\mathrm{Fe}(\mathrm{CN})_{6}\right]$ (2 equiv.) in the basic solution of $\mathrm{KOH}$ (2 equiv.) led to the formation of $\mathrm{S}_{\mathrm{N}^{\mathrm{H}}}$ products $\mathbf{1 3} \mathbf{a}-\mathbf{e}, \mathbf{1 4} \mathbf{b}$ with good yields $(59-67 \%)$ (Scheme $6)$.

\subsection{Anticoagulant activity of the target compounds in vitro}

Firstly, we studied direct oral anticoagulant drugs used in clinical practice - thrombin (Ila factor) inhibitor dabigatran etexilate (Boehringer Ingelheim Pharma GmbH and Co., Germany) and Xa factor inhibitor apixaban (Bristol-Myers Squibb Manufacturing Company, Puerto Rico). The effect on coagulogram parameters was determined in in vitro experiments. We have observed that both drugs at a concentration of $100 \mu \mathrm{M}$ significantly increased the activated partial thromboplastin time (APTT) by 1.7 and 2.9 times relative to control, respectively (Table 1). Dabigatran etexilate in the studied concentration increased thrombin time (TT) by 6.3 times, which corresponds to the mechanism of its anticoagulant action - a disruption of the final stage of coagulation while slightly increasing prothrombin time. Another anticoagulant drug apixaban increased prothrombin time (PT) by 4.6 times, which reflects the external activation pathway of the blood coagulation system and also indicates anticoagulant activity.

The study of target azolo[1,5-a]pyrimidine derivatives and their condensed analogs was performed analogously, as an influence on the parameters of coagulogram of rabbit blood. The results are summarized in Table 1. It was shown that compound $\mathbf{3 n}$ has the greatest ability to prolong thrombin time, exceeding the comparison drug dabigatran etexilate by 2.1 times. Compounds $3 \mathbf{a}$ and $3 \mathrm{~m}$ were 1.9 time superior to dabigatran etexilate; $3 \mathbf{k}$ - superior by 1.6 times. Compound $\mathbf{6 c}$ was comparable in activity to dabigatran etexilate. Other substances also significantly prolonged thrombin time relative to control, but to a lesser extent than comparison drug. None of the studied compounds affected the prothrombin time, unlike apixaban.

Table 1 - Effect of derivatives of azolo[1,5-a]pyrimidines and their condensed analogs on the parameters of the coagulogram of rabbit blood in vitro at a concentration of $100 \mu \mathrm{M}$ $(\mathrm{M} \pm \mathrm{m}, \mathrm{n}=5)$

APTT - activated partial thromboplastin time; TT - thrombin time; PT - prothrombin time 


\begin{tabular}{|c|c|c|c|c|}
\hline \multirow{2}{*}{ No. } & \multirow{2}{*}{ Compound } & \multicolumn{3}{|c|}{ Coagulogram parameter } \\
\hline & & APTT, sec. & $\mathrm{TT}$, sec. & PT, sec. \\
\hline & Control & $47.2 \pm 0.3$ & $11.7 \pm 0.1$ & $14.6 \pm 0.1$ \\
\hline 1. & Dabigatran etexilate & $79.6 \pm 4.6^{*}$ & $69.5 \pm 4.5^{*}$ & $16.7 \pm 0.2$ \\
\hline 2. & Apixaban & $137.5 \pm 2.8^{* \#}$ & $14.6 \pm 0.1^{*}$ & $67.8 \pm 2.5^{* \#}$ \\
\hline 3. & $3 a$ & $65.3 \pm 3.7$ & $108.7 \pm 9.9^{* \#}$ & $13.9 \pm 0.4$ \\
\hline 4. & $3 b$ & $63.7 \pm 4.8$ & $37.9 \pm 1.6^{*}$ & $10.8 \pm 0.5$ \\
\hline 5. & $3 c$ & $51.8 \pm 1.3$ & $29.1 \pm 3.4^{*}$ & $11.0 \pm 0.2$ \\
\hline 6. & $3 d$ & $58.8 \pm 1.9$ & $33.7 \pm 2.1^{*}$ & $11.6 \pm 0.2$ \\
\hline 7. & $3 e$ & $58.0 \pm 1.9$ & $30.3 \pm 3.5^{*}$ & $9.9 \pm 0.1$ \\
\hline 8. & $3 \mathrm{f}$ & $50.8 \pm 1.7$ & $28.4 \pm 1.3^{*}$ & $10.1 \pm 0.8$ \\
\hline 9. & $3 g$ & $63.2 \pm 1.8$ & $30.1 \pm 2.7^{*}$ & $10.4 \pm 0.4$ \\
\hline 10. & $3 h$ & $50.4 \pm 3.0$ & $29.1 \pm 0.6^{*}$ & $10.1 \pm 0.5$ \\
\hline 11. & $3 \mathbf{j}$ & $51.8 \pm 1.4$ & $31.0 \pm 4.3^{*}$ & $10.4 \pm 0.7$ \\
\hline 12. & $3 k$ & $50.6 \pm 2.1^{*}$ & $97.9 \pm 19.1^{*}$ & $13.9 \pm 0.4$ \\
\hline 13. & 31 & $61.1 \pm 4.1$ & $28.5 \pm 2.8^{*}$ & $10.0 \pm 0.6$ \\
\hline 14. & $3 m$ & $63.9 \pm 0.6$ & $134.8 \pm 10.4^{* *}$ & $14.3 \pm 0.6$ \\
\hline 15. & $3 n$ & $55.5 \pm 0.8$ & $146.7 \pm 5.2^{* \sharp}$ & $13.8 \pm 0.1$ \\
\hline 16. & 30 & $52.9 \pm 1.0$ & $31.7 \pm 3.9^{*}$ & $10.9 \pm 0.7$ \\
\hline 17. & $3 p$ & $58.0 \pm 4.0$ & $34.8 \pm 3.2^{*}$ & $10.4 \pm 0.3$ \\
\hline 18. & $3 q$ & $59.5 \pm 1.9$ & $34.8 \pm 3.3^{*}$ & $10.6 \pm 0.2$ \\
\hline
\end{tabular}




\begin{tabular}{|c|c|c|c|c|}
\hline 19. & $6 a$ & $60.3 \pm 2.8$ & $30.7 \pm 4.9^{*}$ & $10.1 \pm 0.4$ \\
\hline 20. & $6 b$ & $52.4 \pm 1.8$ & $33.4 \pm 5.5^{*}$ & $10.5 \pm 0.2$ \\
\hline 21. & $6 c$ & $64.9 \pm 2.7^{*}$ & $64.5 \pm 9.1^{*}$ & $13.9 \pm 0.2$ \\
\hline 22. & 9 & $63.4 \pm 4.0$ & $53.2 \pm 9.1^{*}$ & $11.9 \pm 0.6$ \\
\hline 23. & $13 a$ & $62.7 \pm 8.8$ & $37.0 \pm 4.0^{*}$ & $10.8 \pm 0.7$ \\
\hline 24. & $13 b$ & $63.7 \pm 2.0$ & $35.6 \pm 1.2^{*}$ & $10.8 \pm 0.5$ \\
\hline 25. & $13 c$ & $53.1 \pm 1.6$ & $41.6 \pm 1.9^{*}$ & $10.3 \pm 0.4$ \\
\hline 26. & $13 d$ & $58.1 \pm 1.0$ & $40.5 \pm 3.6^{*}$ & $10.2 \pm 0.1$ \\
\hline 27. & $13 e$ & $51.8 \pm 2.9$ & $39.3 \pm 1.7^{*}$ & $11.5 \pm 0.6$ \\
\hline 28. & $14 a$ & $64.7 \pm 5.8$ & $40.0 \pm 1.8^{*}$ & $11.3 \pm 0.9$ \\
\hline
\end{tabular}

Notes:

* - $(\mathrm{p} \leq 0.05)$ changes are statistically significant vs. control, 1-way ANOVA;

\# - $(\mathrm{p} \leq 0.05)$ changes are statistically significant vs. dabigatran etexilate, 1-way ANOVA.

\subsection{Iterative neural network pharmacophore analysis}

To identify the pharmacophore, an integral structural fragment that provides a high level of FIIa (thrombin serine proteases) inhibitory activity of the tested compounds, an iterative pharmacophore analysis was carried out using artificial neural networks, implemented according to the following scheme:

I. Preprocessing of the source data.

Structures of all tested compounds (3a-14a) (Table 1) were characterized with a matrix of QL-descriptors of the $2^{\text {nd }}$ rank of the $5^{\text {th }}$ type using IT Microcosm system [8]. This type of QL-descriptors contains designations of two simple fragments of the structure of the compound (structural descriptors), which, due to electron-donor or electron-acceptor properties, can ensure the interaction of the molecule with the biological target; an example is a descriptor $\left\{\mathrm{NH}_{2} \ldots>\mathrm{NH}\right\}$. Paths between two structural descriptors can only pass through carbon chains. Based on the obtained QL-descriptor matrix, with the addition of experimental values of FIIa inhibitory activity (TT values from Table 1), an initial training sample was formed, which was then used in the neural network modeling procedure.

II. Iterative neural network modeling.

Per Kolmogorov's theorem [9] using a two-layer artificial neural network, a dependence of any complexity can be approximated, and it was necessary to ensure that signals from many input neurons were convoluted into a small number of intermediate images. Therefore, in the present work the architecture of a two-layer perceptron with a narrow throat MLP k-m-1 was used in neural network modeling of regression dependence, where the number of input neurons $\mathrm{k}>>\mathrm{m}$ of the number of hidden neurons. 
Calculations were performed using Statistica package [10]. Iterative training of networks with selection of sensitive neurons was performed according to the following algorithm:

1. In the standard mode of the Statistica program initial dataset was divided into training, test and validation sets in $70-15-15 \%$ ratio. A total of 100 networks were trained with the automatic selection of 25 neural networks with high values of correlation coefficients.

2. Out of 25 optimal neural networks one best performing network was picked manually according to the set of three values of the correlation coefficients.

3. For the selected best neural network, sensitivity analysis of the input neurons was performed. The dimensionless sensitivity index Sens was calculated, which reflects the relative contribution of each neuron to the formation of the final signal of the output neuron.

4. If during sensitivity analysis neurons with Sens $<1.0$ were found, they were removed from the initial training sample and iterative neural network modeling was carried outstarting from step 1 of this scheme.

5. Otherwise, the process of iterative training of networks was completed and for the best neural network, the overall accuracy of the prediction was assessed on the complete data set.

6. In the best neural network the most sensitive input neurons with Sens $\geq 1.1$ were identified that corresponds to QL-descriptors most significantly affecting the level of FIIainhibitory activity of the studied compounds.

III. Post-processing of the data obtained.

1. Superposition of the significant QL-descriptors found in stage II derive the pharmacophore, which provides a high level of FIla-inhibitory activity of the tested compounds.

2. Analysis of entry of the constructed pharmacophore into the structure of the most active compounds was performed.

The best performing neural network was obtained after seven iterations, during which a total of about 1000 neural networks were trained and analyzed. The main characteristics of the results of each iteration are shown in Table 2.

Table 2 - Neural networks were obtained after iterative modeling

\begin{tabular}{ccccc}
\hline \multirow{2}{*}{ № } & Network architecture & \multicolumn{3}{c}{ Correlation coefficient } \\
\cline { 3 - 5 } Iteration & & Training & Test & Validation \\
\hline 1 & MLP126-9-1BFGS65ExpTanh & 0.782 & 0.999 & 0.997 \\
2 & MLP102-10-1BFGS29ExpIdent & 0.781 & 0.999 & 0.999 \\
3 & MLP 85-8-1BFGS23ExpTanh & 0.781 & 0.999 & 0.999 \\
4 & MLP 71-6-1BFGS23ExpTanh & 0.782 & 0.999 & 0.985 \\
5 & MLP 67-11-1BFGS23LogistTanh & 0.782 & 0.999 & 0.829 \\
6 & MLP 66-11-1BFGS25TanhIdent & 0.781 & 0.999 & 0.980
\end{tabular}


Notes:

MLP - multilayer perceptron;

k-m-1 - the number of input, hidden and output neurons;

BFGSN - algorithm for finding the minimum error function;

Exp, Tanh, Ident, Logist - activation functions of the hidden and output layers of neurons, exponential, hyperbolic tangent, identical, logistic, respectively.

For the best neural network model obtained as a result of the seventh iteration, the correlation coefficient on the combined dataset was $R=0.853\left(p<5 \times 10^{-7}\right)$.

Five types of QL-descriptors that correspond to neurons with Sens $\geq 1.1$ and significantly affecting the level of FIIa-inhibitory activity of new compounds were elucidated: $\quad\{-\mathrm{N}=\ldots=\mathrm{O}\}$, Sens $=1.22 ; \quad\{-\mathrm{N}=\ldots$ CycAr06 $\}$, Sens = 1.27; $\{-\mathrm{N}=\ldots$ CycAr05 $\}$, Sens $=1.23 ;\{-\mathrm{N}<\ldots=\mathrm{O}\}$, Sens $=1.10 ;\left\{-\mathrm{CH}_{3} \ldots>\mathrm{C}(<)\right\}$, Sens $=1.10$. The combination of these binding points forms a pharmacophore that provides a high level of FIIa-inhibitory activity of the tested compounds (Fig. 1).
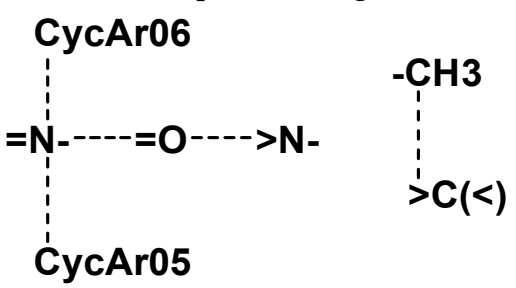

Fig. 1. Pharmacophore that defines a high level of FIIa-inhibitory activity of novel compounds

Incorporation of the constructed pharmacophore into the structures of the three most active compounds and dabigatran etexilate is shown in Table 3.

Table 3 - Entry of the identified pharmacophore into structures of the most active FIIainhibitors and dabigatran etexilate<smiles></smiles>

3n<smiles>CCOC(=O)c1nc2[nH]cc(C(=O)OCCl)c(=O)n2n1</smiles>

$3 a$

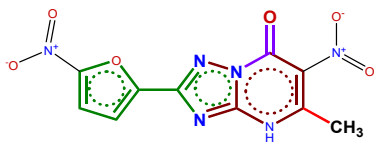

$3 \mathrm{~m}$

$$
\begin{array}{ccc}
\{-\mathrm{N}=\ldots \text {.CycAr06 }\}-1 & \{-\mathrm{N}=\ldots=\mathrm{O}\}-2 & \{-\mathrm{N}=\ldots \mathrm{CycAr06}\}-1 \\
\{-\mathrm{N}=\ldots \text { CycAr05 }\}-4 & \{-\mathrm{N}=\ldots \text { CycAr06 }\}-1 & \{-\mathrm{N}=\ldots \mathrm{CycAr05}\}-4 \\
\{-\mathrm{N}<\ldots=\mathrm{O}\}-1 & \{-\mathrm{N}=\ldots \text { CycAr05 }\}-2 & \\
\text { Total }-6 & \{-\mathrm{N}<\ldots=\mathrm{O}\}-2 & \{\mathrm{CH} 3 \ldots>\mathrm{C}(<)\}-1 \\
& \{-\mathrm{CH} 3 \ldots>\mathrm{C}(<)\}-2 & \text { Total }-7
\end{array}
$$




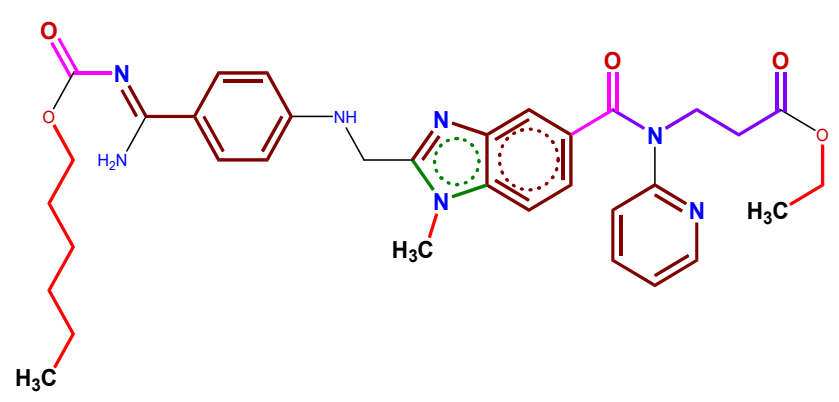

Dabigatranetexilate

$$
\begin{gathered}
\{-\mathrm{N}=\ldots=\mathrm{O}\}-2 \\
\{-\mathrm{N}=\ldots \mathrm{CycAr06}\}-3 \\
\{-\mathrm{N}=\ldots \mathrm{CycAr05}\}-1 \\
\{-\mathrm{N}<\ldots=\mathrm{O}\}-3 \\
\{-\mathrm{CH} 3 \ldots>\mathrm{C}(<)\}-9
\end{gathered}
$$

Total -18

The structure of compound 3a includes a complete pharmacophore of 9 entries of five types of QL-descriptors of a high level of FIIa-inhibitory activity, compound 3m contains 7 entries of four types of QL-descriptors of this pharmacophore, and in the structure of the compound 3n only 6 entries of three types of QL-descriptors are present.

Structure of dabigatran also includes a complete pharmacophore with 18 entries of five types of QL-descriptors of a high level of FIIa-inhibitory activity, and almost all of the found pharmacophore fragments occur in its molecule several times.

\subsection{Anticoagulant activity after LPS treatment}

Sepsis is known as one of the severe complications of various microbial and viral infections, including COVID-19 caused by SARS-CoV-2, characterized by thromboinflammation [1]. Normally, this so-called immunocoagulation is a part of innate immunity and can serve as the first line of defense against infection. It is known that coagulation can be activated by external and internal pathways, resulting in fibrin formation. Preclinical and clinical studies have confirmed the pathological role of tissue factor, the initiator of the external pathway, in the development of endotoxemia [11,12]. It has been experimentally shown that exogenous lipopolysaccharide (LPS) can cause the expression and release of tissue factor on the surface of cells and lead to septic death of mice $[13,14]$. In addition, hypercytokinemia, which is observed during sepsis, causes not only activation of clotting factors, but also suppresses anticoagulant pathways, for 
example, the antithrombin system, activated protein $C$ and tissue factor inhibitor, thereby leading to DIC syndrome and fibrin deposition in blood vessels and tissues [15].

In this regard, compounds $\mathbf{3 a}, \mathbf{3 k}, \mathbf{3 m}, \mathbf{3 n}$, which demonstrated the greatest antithrombin activity in in vitro experiment, were investigated further for the effect on parameters of coagulogram of rabbit blood treated with LPS to mimic conditions of hypercytokinemia (Table 4). Coagulation parameters of LPS-treated blood did not change, except for APTT, which was significantly lengthened by 1.2 times compared to the intact blood sample. At the same time, the reference drugs dabigatran etexilate and apixaban reliably prolonged APTT by 2.6 and 2.8 times, respectively. Also, treatment with dabigatran etexilate significantly increased thrombin time by 1.8 times, and treatment with apixaban by 1.4 times, respectively. The studied compounds had a significant effect only on the thrombin time, reliably exceeding the control values of LPS-treated blood by 6.5-15.2 times.

Table 4 - Effect of compounds on the parameters of coagulogram of rabbit blood treated with LPS in vitro in a concentration of $100 \mu \mathrm{M}(\mathrm{M} \pm \mathrm{m}, \mathrm{n}=5)$

\begin{tabular}{cccc}
\hline Compound & \multicolumn{3}{c}{ Parameters of coagulogram } \\
\cline { 2 - 4 } & APTT, sec. & TT, sec. & PT, sec. \\
\hline Control & $47.18 \pm 0.34$ & $11.65 \pm 0.06$ & $14.60 \pm 0.10$ \\
LPS control & $56.28 \pm 1.60^{*}$ & $13.131 \pm 1.63$ & $15.10 \pm 0.07$ \\
Dabigatran etexilate & $145.33 \pm 25.17^{* \sharp}$ & $125.45 \pm 1.54^{* \sharp}$ & $16.77 \pm 0.20$ \\
Apixaban & $156.3 \pm 7.5^{* *}$ & $15.5 \pm 0.1^{*}$ & $97.0 \pm 5.3^{* \sharp}$ \\
3a & $65.73 \pm 2.50^{*}$ & $141.62 \pm 12.55^{* \sharp}$ & $16.38 \pm 0.35^{*}$ \\
3k & $51.52 \pm 2.26$ & $116.9316 \pm 16.79^{* \sharp}$ & $15.75 \pm 0.74$ \\
$3 m$ & $62.27 \pm 1.07^{*}$ & $85.05 \pm 4.99^{* \sharp}$ & $15.75 \pm 0.19$ \\
$3 n$ & $61.43 \pm 0.49^{*}$ & $199.82 \pm 4.39^{* * \$}$ & $15.20 \pm 0.15$ \\
\hline
\end{tabular}

Notes:

* - ( $\mathrm{p} \leq 0.05)$ changes are statistically significant vs. control, 1-way ANOVA;

\# - $(\mathrm{p} \leq 0.05)$ changes are statistically significant vs. LPS-control, 1-way ANOVA;

$\$$ - $(p \leq 0.05)$ changes are statistically significant vs. dabigatran etexilate, 1-way ANOVA.

As compounds $3 \mathbf{a}$ and $\mathbf{3 n}$ showed the greatest anticoagulant effect on LPS-treated blood we determined their half-maximum effective concentrations ( $\mathrm{IC}_{50}$ ) on intact and LPS-treated blood. As shown in Table 5, the potency of compounds $\mathbf{3 a}$ and $\mathbf{3 n}$ as the effect on thrombin time of intact blood exceeds the comparison drug by 1.8 and 1.6 times.

Table 5 - IC 50 of compounds $\mathbf{3 a}$ and $\mathbf{3 n}$ of thrombin time prolongation with and without LPS in vitro. 


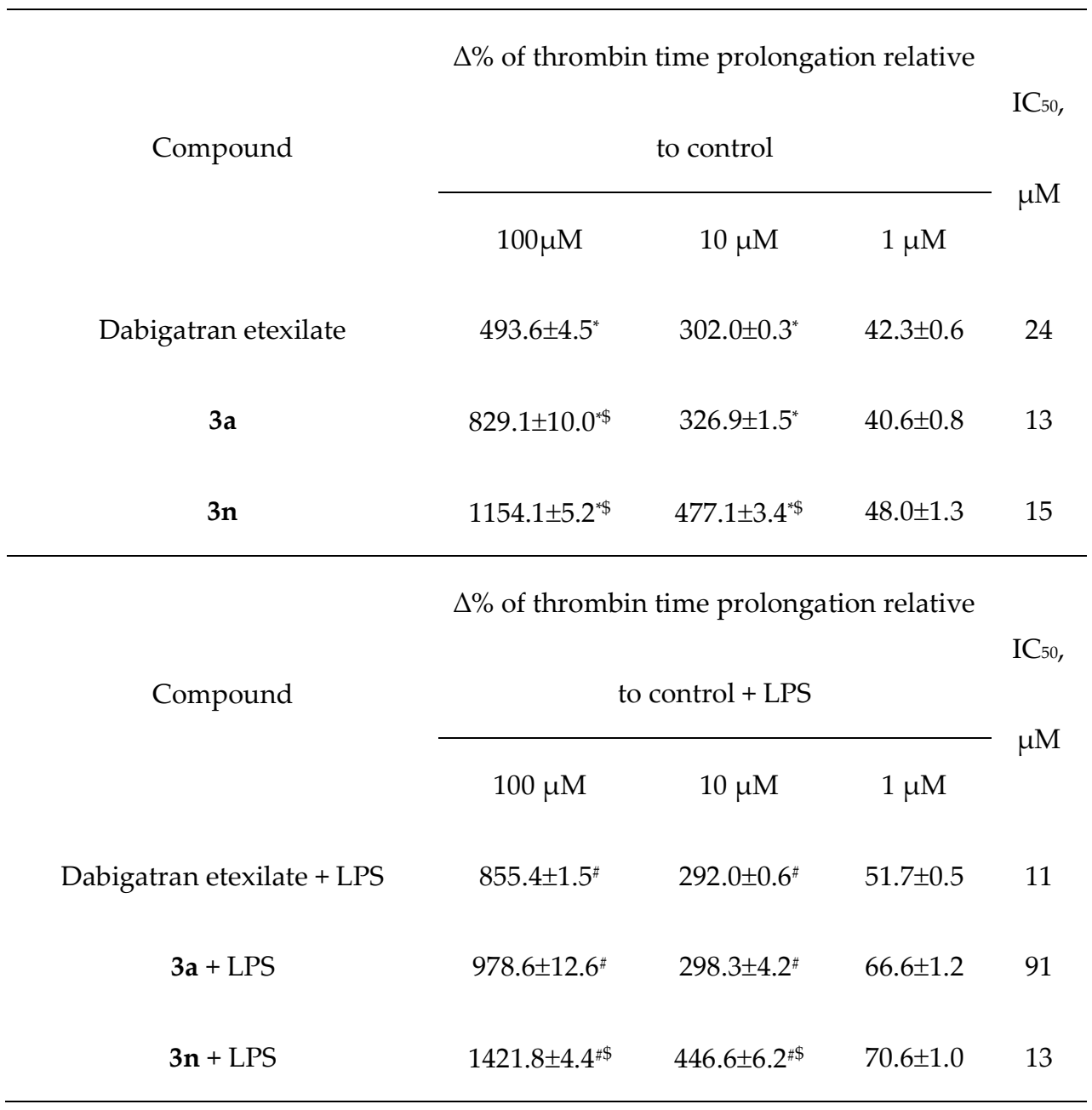

Notes:

"- ( $\mathrm{p} \leq 0.05)$ changes are statistically significant vs. control, 1-way ANOVA;

\# - ( $\mathrm{p} \leq 0.05)$ changes are statistically significant vs. LPS-control, 1-way ANOVA;

$\$$ - $(\mathrm{p} \leq 0.05)$ changes are statistically significant vs. dabigatranetexilate, 1-way ANOVA.

\subsection{An animal study of anticoagulant activity}

Compounds $3 \mathbf{a}$ and $\mathbf{3 n}$, which demonstrated in vitro activity comparable to the reference drug dabigatran etexilate both on intact blood and under conditions of hypercytokinemia, were studied in in vivo experiments on rats in doses equimolar to the dabigatran etexilate after a single intragastric administration. Parameters of the obtained coagulograms in experiments on whole animals at various time points are presented in Table 6.

Table $\mathbf{6}$ - Effect of compounds $\mathbf{3 a}$ and $\mathbf{3 n}$ in equimolar dabigatran etexilate doses on the coagulogram of rats with a single intragastric administration $(M \pm m, n=5)$

\begin{tabular}{|c|c|c|c|c|c|}
\hline \multirow{2}{*}{ Sample } & \multirow{2}{*}{$\begin{array}{l}\text { Dose, } \\
\text { mg/kg }\end{array}$} & \multirow{2}{*}{ Time, $\mathrm{h}$} & \multicolumn{3}{|c|}{ Coagulogram parameters } \\
\hline & & & APTT, sec. & TT, sec. & PT, sec. \\
\hline
\end{tabular}




\begin{tabular}{|c|c|c|c|c|c|}
\hline Control & & & $38.3 \pm 1.7$ & $57.7 \pm 3.8$ & $28.1 \pm 1.4$ \\
\hline \multirow[t]{2}{*}{ Dabigatran etexilate } & $12.0^{1}$ & $2^{\#}$ & $137.53 \pm 2.79^{*}$ & $637.4 \pm 5.1^{*}$ & $31.20 \pm 1.17$ \\
\hline & & 1 & $32.2 \pm 0.8$ & $40.9 \pm 6.0$ & $24.9 \pm 0.8$ \\
\hline \multirow[t]{3}{*}{$3 a$} & $5.4^{\$}$ & 2 & $37.2 \pm 1.2$ & $60.7 \pm 6.0$ & $26.4 \pm 0.4$ \\
\hline & & 4 & $33.3 \pm 0.7$ & $64.8 \pm 3.4$ & $27.7 \pm 0.7$ \\
\hline & & 1 & $27.9 \pm 2.3$ & $68.6 \pm 3.4$ & $29.3 \pm 1.3$ \\
\hline \multirow[t]{2}{*}{$3 n$} & $5.8^{\$}$ & 2 & $28.5 \pm 1.3$ & $65.5 \pm 6.1$ & $28.4 \pm 1.6$ \\
\hline & & 4 & $27.0 \pm 2.7$ & $78.5 \pm 1.6^{*}$ & $31.2 \pm 1.2$ \\
\hline
\end{tabular}

Notes:

1 - dose obtained by recalculation using the interspecies coefficient;

$\$$ - dose, equimolar to $12.0 \mathrm{mg} / \mathrm{kg}$ of dabigatran etexilate;

* - $\mathrm{p} \leq 0.05$ ) changes are statistically significant vs. control, 1-way ANOVA;

\# - time to reach the maximum plasma concentration of dabigatran etexilate.

$\mathrm{n}$ - number of experimental animals

We observed that compound 3a 1,2 and 4 hours after oral administration did not affect the thrombin time, while compound $3 \mathrm{n}$ reliably prolonged this parameter by 1.4 times 4 hours after oral administration.

Also, the efficiency of these compounds was investigated using thromboelastography analysis, the results are shown in Table 7.

Table 7 - Effect of compounds $\mathbf{3 a}$ and $\mathbf{3 n}$ on thromboelasteogram (TEG) of rats with a single intragastric administration $(M \pm m, n=5)$

TEG parameters

Dose, Time, $\alpha$-Angle,

Sample

$\mathrm{mg} / \mathrm{kg} \quad \mathrm{h} \quad \mathrm{R}, \mathrm{min} . \quad K, \mathrm{~min} . \mathrm{deg} . \quad M A, \mathrm{RU}$

Control

$6.4 \pm 0.9 \quad 2.5 \pm 0.1 \quad 61.5 \pm 2.3$

$65.5 \pm 1.2$

Dabigatran

$\begin{array}{lllll}12.0^{1} \quad 2^{\#} & 22.8 \pm 3.3^{*} & 16.8 \pm 2.8^{*} & 14.1 \pm 3.1^{*} & 37.1 \pm 7.9^{*}\end{array}$

etexilate

$3 a$

$\begin{array}{lllll}5.4^{\$} & 1 & 7.3 \pm 0.6 & 2.9 \pm 0.4 & 55.2 \pm 3.5\end{array}$

$68.2 \pm 1.9$ 


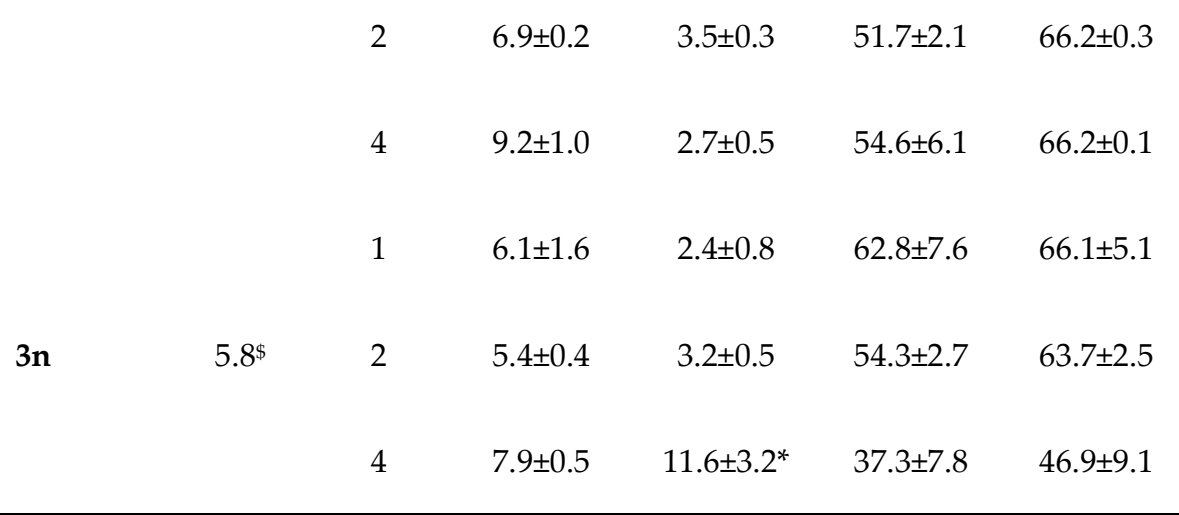

Notes:

1 - dose obtained by recalculation using the interspecies coefficient;

$\$$ - dose, equimolar to $12.0 \mathrm{mg} / \mathrm{kg}$ of dabigatran etexilate;

* $-(\mathrm{p} \leq 0.05)$ changes are statistically significant vs. control, 1-way ANOVA;

${ }^{*}$ - time to reach the maximum plasma concentration of dabigatran etexilate;

$\mathrm{n}$ - number of experimental animals;

$\mathrm{R}$ - time to formation of the first fibrin filaments;

$\mathrm{K}$ - time from $\mathrm{R}$ until the clot reaches $20 \mathrm{~mm}$;

$\alpha$-Angle - the tangent of the curve made as the $\mathrm{K}$ is reached;

MA - maximum amplitude characterizing the functional activity of platelets and clot strength.

The reference drug dabigatran etexilate prolonged the time to the first evidence of clot formation by 3.6 times, increased the $\mathrm{K}$ value by 6.7 times, reduced the rate of clot formation by 4.4 times, and also reduced the maximum strength of the clot by 1.8 times relative to control values. The data obtained confirm the anticoagulant activity of dabigatran etexilate. Compound $\mathbf{3 a}$ and $\mathbf{3} \mathbf{n}$ in doses equimolar to dabigatran during 4 hours of observation did not have a significant effect on the time of formation of the first filaments of fibrin, the rate of clot formation or the maximum amplitude. Compound $\mathbf{3 n}$ 4 hours after administration significantly increased the time from the beginning of clot formation until it reached an amplitude of $20 \mathrm{~mm}$.

As the next step of the study, the ability of compounds $3 \mathbf{a}$ and $3 \mathbf{n}$ to affect coagulogram parameters in rats was assessed in $2 x$ and $4 x$ increased dose (of the dose equimolar to dabigatran etexilate), results are shown in Table 8.

Table 8 - Effect of compounds $3 \mathbf{a}$ and $\mathbf{3 n}$ on the coagulogram of rats after a single intragastric administration at various intervals in increased doses $(M \pm m, n=5)$

\begin{tabular}{cccccc}
\hline \multirow{2}{*}{ Sample } & Dose, & Time, & \multicolumn{3}{c}{ Coagulogram parameters } \\
\cline { 4 - 6 } & & & & & \\
\cline { 4 - 6 } & $\mathrm{mg} / \mathrm{kg}$ & $\mathrm{h}$ & APTT, sec. & TT, sec. & PT, sec. \\
\hline Control & & & $38.3 \pm 1.7$ & $57.7 \pm 3.8$ & $28.1 \pm 1.4$ \\
Dabigatran etexilate & $12.0^{1}$ & $2^{*}$ & $140.1 \pm 8.1^{*}$ & $637.4 \pm 5.1^{*}$ & $30.5 \pm 0.8$ \\
3a & 10.8 & 1 & $35.9 \pm 0.3$ & $66.5 \pm 11.0$ & $29.1 \pm 1.9$
\end{tabular}




$\begin{array}{ccccc} & 2 & 35.8 \pm 1.5 & 67.2 \pm 5.6 & 25.8 \pm 0.6 \\ & 4 & 35.4 \pm 1.4 & 57.9 \pm 6.4 & 26.2 \pm 1.6 \\ & 1 & 37.0 \pm 0.8 & 194.4 \pm 19.8^{*} & 25.4 \pm 1.3 \\ & & & & \\ & 2 & 32.3 \pm 0.2 & 186.9 \pm 2.5 & 22.9 \pm 4.4 \\ & 4 & 36.1 \pm 1.2 & 198.3 \pm 26.7^{*} & 28.7 \pm 1.4 \\ & & & & \\ & & & & \\ 23.2 & 2 & 31.6 \pm 1.5 & 655.6 \pm 2.1^{*} & 29.3 \pm 0.6 \\ & & & & \\ & 4 & 34.4 \pm 0.7 & 95.6 \pm 25.8 & 21.8 \pm 0.9\end{array}$

Notes:

1 - dose obtained by recalculation using the interspecies coefficient;

* $-(\mathrm{p} \leq 0.05)$ changes are statistically significant vs. control, 1-way ANOVA;

\# - time to reach the maximum plasma concentration of dabigatran etexilate;

$\mathrm{n}$ - number of experimental animals;

With the dose of $3 \mathrm{n}$ increased 2 times $(11.6 \mathrm{mg} / \mathrm{kg}) 1,2$ and 4 hours after intragastric administration a significant prolongation of thrombin time was observed (3.4 times). Further $3 \mathrm{n}$ dose increase to $23.2 \mathrm{mg} / \mathrm{kg}$ resulted in the highest anticoagulant activity comparable to $12 \mathrm{mg} / \mathrm{kg}$ dabigatran in terms of thrombin time, while other parameters of the TEG remained unaffected. Compound $\mathbf{3 a}$ in 2 times increased dose did not affect any of the investigated parameters of the coagulogram.

Thromboelastography dose-elevating study of compound $\mathbf{3 a}$ has shown that compound did not affect the parameters of the thromboelastogram, which corresponds to the data obtained in the rat blood coagulogram study (Table 9).

Compound $3 \mathrm{n}$ in a 2 times increased dose (compared to the dose equimolar to dabigatran etexilate) showed the greatest activity 4 hours after administration, as it prolonged the time to the first fibrin filaments formation by 1.9 times, increased the $\mathrm{K}$ value by 3.6 times, reduced the rate of clot formation by 2.5 times, and also reduced the maximum strength of the clot by 1.4 times relative to the control values.

With a further increase in the dose of the compound $3 \mathrm{n}$ to $23.2 \mathrm{mg} / \mathrm{kg}$ an anticoagulant effect was reliably observed 1 hour after intragastric administration. After 4 hours, TEG showed a statistically significant 4.1 times reduced rate of clot formation and 1.9 times reduced clot strength, which is comparable to the effect of dabigatran etexilate.

Table 9 - Effect of compounds $3 \mathbf{a}$ and $3 \mathbf{n}$ on the TEG of rats after a single intragastric administration at various intervals in an increased doses $(M \pm m, n=5)$ 


\begin{tabular}{|c|c|c|c|c|c|c|}
\hline & \multirow{4}{*}{\multicolumn{2}{|c|}{$\begin{array}{c}\text { Time, } \\
\text { h }\end{array}$}} & \\
\hline & & & \multirow{3}{*}{$R, \min }$. & \multirow{3}{*}{$K, \min }$. & \multirow{3}{*}{$\begin{array}{c}\alpha \text {-Angle, } \\
\text { deg. }\end{array}$} & \multirow{3}{*}{$\begin{array}{l}M A \\
\text { RU }\end{array}$} \\
\hline & & & & & & \\
\hline & & & & & & \\
\hline Control & & & $6.4 \pm 0.9$ & $2.5 \pm 0.1$ & $61.5 \pm 2.3$ & $65.5 \pm 1.2$ \\
\hline \multicolumn{7}{|l|}{ Dabigatran } \\
\hline \multirow{2}{*}{ etexilate } & $12.0^{1}$ & $2^{\#}$ & $22.8 \pm 3.3^{*}$ & $16.8 \pm 2.8^{*}$ & $14.1 \pm 3.1^{*}$ & $37.1 \pm 7.9^{*}$ \\
\hline & & 1 & $8.1 \pm 0.6$ & $2.3 \pm 0.1$ & $60.3 \pm 0.1$ & $69.6 \pm 2.3$ \\
\hline \multirow[t]{5}{*}{$3 a$} & 10.8 & 2 & $5.9 \pm 0.4$ & $1.8 \pm 0.3$ & $67.3 \pm 0.4$ & $69.5 \pm 3.3$ \\
\hline & & 4 & $5.9 \pm 0.6$ & $2.3 \pm 0.5$ & $61.1 \pm 3.1$ & $73.3 \pm 2.3$ \\
\hline & & 1 & $6.2 \pm 1.1$ & $4.6 \pm 1.1$ & $41.5 \pm 7.6$ & $52.8 \pm 2.5$ \\
\hline & 11.6 & 2 & $8.7 \pm 0.3$ & $6.2 \pm 0.4^{*}$ & $32.3 \pm 1.5^{*}$ & $50.3 \pm 1.3$ \\
\hline & & 4 & $11.9 \pm 1.0^{*}$ & $8.9 \pm 0.9^{*}$ & $24.5 \pm 1.2^{*}$ & $46.7 \pm 1.6^{*}$ \\
\hline \multirow[t]{3}{*}{$3 n$} & & 1 & $13.6 \pm 1.5^{*}$ & $9.2 \pm 0.9^{*}$ & $29.0 \pm 2.8^{*}$ & $45.1 \pm 3.6^{*}$ \\
\hline & 23.2 & 2 & $9.0 \pm 0.01^{*}$ & $5.0 \pm 1.8$ & $37.4 \pm 6.7^{*}$ & $53.5 \pm 3.6$ \\
\hline & & 4 & $20.1 \pm 8.4$ & $18.1 \pm 7.3$ & $14.9 \pm 6.4^{*}$ & $34.5 \pm 2.9^{*}$ \\
\hline
\end{tabular}

Notes:

1 - dose obtained by recalculation using the interspecies coefficient;

* $-(p \leq 0.05)$ changes are statistically significant vs. control, 1-way ANOVA;

\#- time to reach the maximum plasma concentration of dabigatran etexilate;

$\mathrm{n}$ - number of experimental animals;

\section{Materials and Methods}

\subsection{Chemistry}

Commercial reagents were obtained from Sigma-Aldrich, Acros Organics, or Alfa Aesar and used without any further purification. All workup and purification procedures were carried out using analytical grade solvents. One-dimensional ${ }^{1} \mathrm{H}$ and ${ }^{13} \mathrm{C}$ NMR spectra were acquired on a Bruker DRX-400 instrument (400, and $101 \mathrm{MHz}$, respectively), utilizing $\mathrm{CDCl}_{3}$ and DMSO- $d_{6}$ as solvent and as an external reference. The following abbreviations are used for multiplicity of NMR signals: $\mathrm{s}$ - singlet, $\mathrm{d}$ - doublet, $\mathrm{t}$ - triplet, $\mathrm{q}$ quartet, dd - double of doublets, $\mathrm{m}$ - multiplet, br - broaded. IR spectra were recorded on a Bruker Alpha spectrometer equipped with a ZnSe ATR accessory. Elemental analysis 
was performed on a PerkinElmer PE 2400 elemental analyzer. Melting points were determined on a Stuart SMP3 and are uncorrected. The monitoring of the reaction progress was performed by using TLC on Silufol UV254 plates (eluent is $\mathrm{CHCl}_{3}$ ). Heterocycles $\mathbf{3 b} \mathbf{b} \mathbf{3 d}$, 3e, 7, 10a, 10b were synthesized in accordance with literature data: $\mathbf{3 b}$ [16], 3d, 3e [17], 7 [18], 10a, 10b [19]. All synthesized compounds are $>95 \%$ pure by elemental analysis.

General procedure for the synthesis of 2-R-6-ethoxycarbonyl-1,2,4-triazolo[1,5-a]pyrimidin7-ones $(3 a, 3 f)$.

A suspension of $0.0030 \mathrm{~mol}$ (1 eq.) of the corresponding 3-R-5-amino-1,2,4-triazole 1a, 1f and $0.0032 \mathrm{~mol}$ (1.07 eq.) of diethyl ethoxymethylenemalonate $2 \mathrm{a}$ in $6.0 \mathrm{ml}$ of glacial $\mathrm{AcOH}$ was stirred at reflux $\left(130^{\circ} \mathrm{C}\right.$ oil bath temperature) for 5 hours. The reaction mixture was cooled to $25^{\circ} \mathrm{C}$, the obtained precipitate was filtered off and washed with $10 \mathrm{ml}$ of $i$ $\mathrm{PrOH}$ to give the analytical pure product.

2,6-Diethoxycarbonyl-1,2,4-triazolo[1,5-a]pyrimidin-7-one (3a).

White powder $\left(1.04 \mathrm{~g}\right.$, yield 75\%), m.p. 266-267 ${ }^{\circ} \mathrm{C}$. FT-IR (neat) $v_{\max }\left(\mathrm{cm}^{-1}\right): 1764$ $(\mathrm{C}=\mathrm{O}), 1732(\mathrm{C}=\mathrm{O}), 1642(\mathrm{C}=\mathrm{O}) .{ }^{1} \mathrm{H}$ NMR (400 MHz, DMSO-d6) $\delta(\mathrm{ppm}) 1.29(3 \mathrm{H}, \mathrm{t}, J=7.1$ $\left.\mathrm{Hz}, \mathrm{OCH}_{2} \underline{\mathrm{C}}_{3}\right), 4.26\left(2 \mathrm{H}, \mathrm{q}, J=7.1 \mathrm{~Hz}, \mathrm{OC}_{2} \mathrm{CH}_{3}\right), 4.39\left(2 \mathrm{H}, \mathrm{q}, J=7.1 \mathrm{~Hz}, \mathrm{OC}_{2} \mathrm{CH}_{3}\right), 8.72$ $(1 \mathrm{H}, \mathrm{s}, \mathrm{H}-2) .{ }^{13} \mathrm{C}\left\{{ }^{1} \mathrm{H}\right\} \mathrm{NMR}\left(100 \mathrm{MHz}, \mathrm{DMSO}-d_{6}\right) \delta$ (ppm) 14.0, 14.2, 60.5, 61.7, 102.9, 147.7, 150.9, 152.8, 153.6, 159.3, 162.9. Anal. Calcd. for $\mathrm{C}_{11} \mathrm{H}_{12} \mathrm{~N}_{4} \mathrm{O}_{5}$ : C 47.15, H 4.32, N 19.99; found: C 47.22, H 4.29, N 20.09 .

2-(Thien-2-yl)-6-ethoxycarbonyl-1,2,4-triazolo[1,5-a]pyrimidin-7-one (3f).

White powder $(0.74 \mathrm{~g}$, yield $85 \%)$, m.p. $>300{ }^{\circ} \mathrm{C}$. FT-IR (neat) $v_{\max }\left(\mathrm{cm}^{-1}\right): 1739(\mathrm{C}=\mathrm{O})$, $1699(\mathrm{C}=\mathrm{O}), 1630(\mathrm{C}=\mathrm{O}) .{ }^{1} \mathrm{H}$ NMR $\left(400 \mathrm{MHz}, \mathrm{DMSO}-d_{6}\right) \delta(\mathrm{ppm}) 1.28(3 \mathrm{H}, \mathrm{t}, J=7.2 \mathrm{~Hz}$, $\left.\mathrm{OCH}_{2} \underline{\mathrm{H}}_{3}\right), 4.25\left(2 \mathrm{H}, \mathrm{q}, J=7.2 \mathrm{~Hz}, \mathrm{OC}_{\mathrm{H}_{2}} \mathrm{CH}_{3}\right), 7.22\left(1 \mathrm{H}, \mathrm{t}, J=4.0 \mathrm{~Hz}, \mathrm{H}-4^{\prime}\right), 7.74-7.80(2 \mathrm{H}$, m, H-3', H-5'), 8.63 (1H, s, H-5). ${ }^{13} \mathrm{C}\left\{{ }^{1} \mathrm{H}\right\}$ NMR (100 MHz, DMSO-d6) $\delta$ (ppm) 14.2, 60.2, $102.4,128.1,128.3,129.1,132.7,147.9,151.9,153.0,157.5,163.3$. Anal. Calcd. for $\mathrm{C}_{12} \mathrm{H}_{10} \mathrm{~N}_{4} \mathrm{O}_{3} \mathrm{~S}:$ C 49.65 H 3.47 N 19.30; found: C 49.37 H 3.48 N 19.34.

General procedure for the synthesis of 6-nitroazolo[1,5-a]pyrimidin-7-ones (3g-l).

Ethyl ethoxymethylenenitroacetate $2 \mathbf{b}$ (0.01 mol, 1 eq.) was added to a stirred solution of the corresponding 5-amino-1,2,4-triazole 1b, 1d-h or 3-phenyl-4-cyano-5-aminopyrazole $1 \mathrm{~g}$ (0.01 mol, 1 eq.) in a mixture of pyridine $(8.5 \mathrm{ml})$ and glacial acetic acid $(6.0 \mathrm{ml})$ and the mixture was stirred at reflux $\left(145^{\circ} \mathrm{C}\right.$ oil bath temperature $)$ for 6 hours. The obtained precipitate was filtered off and washed with of EtOH.

2-(Pyridin-3-yl)-6-nitro-1,2,4-triazolo[1,5-a]pyrimidin-7-one (3g).

Pale-yellow powder $(1.81$ g, yield $70 \%)$, m.p. > $300 \circ$ C. FT-IR (neat) $v_{\max }\left(\mathrm{cm}^{-1}\right): 1675$ $(\mathrm{C}=\mathrm{O}), 1583\left(\mathrm{NO}_{2}\right), 1264\left(\mathrm{NO}_{2}\right) .{ }^{1} \mathrm{H}$ NMR $\left(400 \mathrm{MHz}, \mathrm{DMSO}-d_{6}\right) \delta(\mathrm{ppm}) 7.48(1 \mathrm{H}, \mathrm{dd}, J=$ 8.0, 4.4 Hz, H-5'), $8.47\left(1 \mathrm{H}, \mathrm{d}, J=8.0 \mathrm{~Hz}, \mathrm{H}-4^{\prime}\right), 8.61\left(1 \mathrm{H}, \mathrm{d}, J=4.4 \mathrm{~Hz}, \mathrm{H}-6^{\prime}\right), 8.99\left(1 \mathrm{H}, \mathrm{s}, \mathrm{H}^{-}\right.$ $\left.2^{\prime}\right), 9.30(1 \mathrm{H}, \mathrm{c}, \mathrm{H}-5) .{ }^{13} \mathrm{C}\left\{{ }^{1} \mathrm{H}\right\} \mathrm{NMR}\left(100 \mathrm{MHz}, \mathrm{DMSO}-d_{6}\right) \delta$ (ppm) 123.2, 123.9, 127.0, 134.0, 147.6, 150.7, 151.0, 153.5, 159.0, 160.1. Anal. Calcd. for $\mathrm{C}_{10} \mathrm{H}_{6} \mathrm{~N}_{6} \mathrm{O}_{3}$ : C 46.52, H 2.34, N 32.55; found: C 46.59, H 2.20, N 32.58 .

Pyridinium 2-phenyl-6-nitro-1,2,4-triazolo[1,5-a]pyrimidin-7-one (3h).

Yellow powder $\left(0.92 \mathrm{~g}\right.$, yield 70\%), m.p. > $300{ }^{\circ} \mathrm{C}$. FT-IR (neat) $v_{\max }\left(\mathrm{cm}^{-1}\right): 1680(\mathrm{C}=\mathrm{O})$, $1629\left(\mathrm{NO}_{2}\right), 1280\left(\mathrm{NO}_{2}\right) .{ }^{1} \mathrm{H}$ NMR $\left(400 \mathrm{MHz}, \mathrm{DMSO}-d_{6}\right) \delta(\mathrm{ppm}) 7.51\left(3 \mathrm{H}, \mathrm{m}, \mathrm{H}-3^{\prime}, \mathrm{H}-4^{\prime}, \mathrm{H}-\right.$ $\left.5^{\prime}\right), 7.93\left(2 \mathrm{H}, \mathrm{m}, \mathrm{H}-2^{\prime}, \mathrm{H}-6^{\prime}\right), 8.13\left(2 \mathrm{H}, \mathrm{d}, J=8.0 \mathrm{~Hz}, \mathrm{H}-3^{\prime \prime}, \mathrm{H}-5^{\prime \prime}\right), 8.43\left(1 \mathrm{H}, \mathrm{m}, \mathrm{H}-4^{\prime \prime}\right), 8.85$ $\left(2 \mathrm{H}, \mathrm{d}, J=5.6 \mathrm{~Hz}, \mathrm{H}-2^{\prime \prime}, \mathrm{H}-6^{\prime \prime}\right), 9.07$ (1H, s, H-5). ${ }^{13} \mathrm{C}\left\{{ }^{1} \mathrm{H}\right\}$ NMR (100 MHz, DMSO-d6) $\delta$ (ppm) 123.7, 126.5 (2C), 126.6 (2C), 128.8 (2C), 130.0, 130.6, 143.6 (2C), 144.5, 150.4, 152.0, 157.4, 161.5. Anal. Calcd. for $\mathrm{C}_{16} \mathrm{H}_{12} \mathrm{~N}_{6} \mathrm{O}_{3}$ : C 57.14, H 3.60, N 24.99; found: 57.01, H 3.85, N 24.80 .

Pyridinium 2-(fur-2-yl)-6-nitro-1,2,4-triazolo[1,5-a]pyrimidin-7-one (3i).

Yellow powder $(0.65 \mathrm{~g}$, yield $60 \%)$, m.p. 225-226 ${ }^{\circ} \mathrm{C}$. FT-IR (neat) $v_{\max }\left(\mathrm{cm}^{-1}\right): 1683$ $(\mathrm{C}=\mathrm{O}), 1616\left(\mathrm{NO}_{2}\right), 1289\left(\mathrm{NO}_{2}\right) .{ }^{1} \mathrm{H}$ NMR $\left(400 \mathrm{MHz}, \mathrm{DMSO}-d_{6}\right) \delta(\mathrm{ppm}) 6.63(1 \mathrm{H}, \mathrm{dd}, J=$ 3.6, $\left.1.6 \mathrm{~Hz}, \mathrm{H}-4^{\prime}\right), 7.08\left(1 \mathrm{H}, \mathrm{d}, J=3.6 \mathrm{~Hz}, \mathrm{H}-3^{\prime}\right), 7.78\left(1 \mathrm{H}, \mathrm{d}, J=1.6 \mathrm{~Hz}, \mathrm{H}-5^{\prime}\right), 7.85(2 \mathrm{H}, \mathrm{t}, J=$ $\left.6.8 \mathrm{~Hz}, \mathrm{H}-3^{\prime \prime}, \mathrm{H}-5^{\prime \prime}\right), 8.33\left(1 \mathrm{H}, \mathrm{t}, J=6.8 \mathrm{~Hz}, \mathrm{H}-4^{\prime \prime}\right), 8.84\left(2 \mathrm{H}, \mathrm{d}, J=4.8 \mathrm{~Hz}, \mathrm{H}-2^{\prime \prime}, \mathrm{H}-6^{\prime \prime}\right), 9.04$ $(1 \mathrm{H}, \mathrm{s}, \mathrm{H}-5) .{ }^{13} \mathrm{C}\left\{{ }^{1} \mathrm{H}\right\} \mathrm{NMR}\left(100 \mathrm{MHz}, \mathrm{DMSO}-d_{6}\right) \delta$ (ppm) 111.0, 111.9, 123.6, 126.7, 143.3, 
143.4, 144.6, 144.8, 144.9, 146.1, 150.3, 152.3, 155.1, 157.4. Anal. Calcd. for $\mathrm{C}_{14} \mathrm{H}_{10} \mathrm{~N}_{6} \mathrm{O}_{4}: \mathrm{C}$ 51.54, H 3.09, N 25.76; found: 51.48, H 3.10, N 25.80.

Pyridinium 2-(thien-2-yl)-6-nitro-1,2,4-triazolo[1,5-a]pyrimidin-7-one (3j).

Yellow powder $\left(2.22 \mathrm{~g}\right.$, yield 65\%), m.p. > $300{ }^{\circ} \mathrm{C}$. FT-IR (neat) $v_{\max }\left(\mathrm{cm}^{-1}\right): 1670(\mathrm{C}=\mathrm{O})$, $1527\left(\mathrm{NO}_{2}\right), 1280\left(\mathrm{NO}_{2}\right) .{ }^{1} \mathrm{H}$ NMR $\left(400 \mathrm{MHz}, \mathrm{DMSO}-d_{6}\right) \delta(\mathrm{ppm}) 7.16(1 \mathrm{H}, \mathrm{dd}, J=4.8,4.8$ Hz, H-4'), $7.58\left(1 \mathrm{H}, \mathrm{d}, J=4.8 \mathrm{~Hz}, \mathrm{H}-3^{\prime}\right), 7.75\left(1 \mathrm{H}, \mathrm{d}, J=4.8 \mathrm{~Hz}, \mathrm{H}-5^{\prime}\right), 7.83$ (2H, m, H-3'”, H$\left.5^{\prime \prime}\right), 8.31\left(1 \mathrm{H}, \mathrm{t}, J=8.0 \mathrm{~Hz}, \mathrm{H}-4^{\prime \prime}\right), 8.81\left(2 \mathrm{H}, \mathrm{d}, J=5.6 \mathrm{~Hz}, \mathrm{H} 2^{\prime \prime}, \mathrm{H}-6^{\prime \prime}\right), 9.05$ (1H, s, H-5). ${ }^{13} \mathrm{C}\left\{{ }^{1} \mathrm{H}\right\}$ NMR (100 MHz, DMSO-d6) $\delta$ (ppm) 123.6, 126.7 (2C), 127.4, 128.1, 128.4, 133.7, 143.5 (2C), 144.6, 150.3, 152.3, 157.5, 158.2. Anal. Calcd. for $\mathrm{C}_{14} \mathrm{H}_{10} \mathrm{~N}_{6} \mathrm{O}_{3} S$ : C 49.12, H 2.94, N 24.55; found: C 49.01, H 3.01, N 24.60.

Pyridinium 2-(5-nitrofur-2-yl)-6-nitro-1,2,4-triazolo[1,5-a]pyrimidin-7-one (3k).

Brown powder $(1.39 \mathrm{~g}$, yield $75 \%)$, m.p. 282-284 ${ }^{\circ}$ C. FT-IR (neat) $v_{\max }\left(\mathrm{cm}^{-1}\right): 3046$, 3138, $1693(\mathrm{C}=\mathrm{O}), 1605\left(\mathrm{NO}_{2}\right), 1540\left(\mathrm{NO}_{2}\right), 1305\left(\mathrm{NO}_{2}\right), 1335\left(\mathrm{NO}_{2}\right) .{ }^{1} \mathrm{H}$ NMR $(400 \mathrm{MHz}$, DMSO- $\left.d_{6}\right) \delta(\mathrm{ppm}) 7.11\left(1 \mathrm{H}, \mathrm{d}, J=3.2 \mathrm{~Hz}, \mathrm{H}-4^{\prime}\right), 7.85\left(1 \mathrm{H}, \mathrm{d}, J=4.8 \mathrm{~Hz}, \mathrm{H}-3^{\prime}\right), 7.99(2 \mathrm{H}, \mathrm{t}, J$ $\left.=6.4 \mathrm{~Hz}, \mathrm{H}-3^{\prime \prime}, \mathrm{H}-5^{\prime \prime}\right), 8.50\left(1 \mathrm{H}, \mathrm{t}, J=8.0 \mathrm{~Hz}, \mathrm{H}-4^{\prime \prime}\right), 8.91\left(2 \mathrm{H}, \mathrm{d}, J=4.8 \mathrm{~Hz}, \mathrm{H} 2^{\prime \prime}, \mathrm{H}-6^{\prime \prime}\right), 9.07$ $(1 \mathrm{H}, \mathrm{s}, \mathrm{H}-5) .{ }^{13} \mathrm{C}\left\{{ }^{1} \mathrm{H}\right\} \mathrm{NMR}\left(100 \mathrm{MHz}, \mathrm{DMSO}-d_{6}\right) \delta$ (ppm) 114.0, 115.1, 124.1, 127.2, 143.9, 145.2, 148.9, 150.8, 152.3, 153.9, 154.0, 159.0. Anal. Calcd. for $\mathrm{C}_{14} \mathrm{H}_{9} \mathrm{~N}_{7} \mathrm{O}_{6}$ : C $45.29 \mathrm{H} 2.44 \mathrm{~N}$ 26.41; found: C $45.45 \mathrm{H} 2.45$ N 26.59.

Pyridinium 2-phenyl-3-cyano-6-nitropyrazolo[1,5-a]pyrimidin-7-one (3l).

Yellow crystals $(1.30 \mathrm{~g}$, yield $60 \%)$, m.p. 249-251 ${ }^{\circ} \mathrm{C}$. FT-IR (neat) $v_{\max }\left(\mathrm{cm}^{-1}\right): 2217$ $(\mathrm{CN}), 1675(\mathrm{C}=\mathrm{O}), 1548\left(\mathrm{NO}_{2}\right), 1282\left(\mathrm{NO}_{2}\right) .{ }^{1} \mathrm{H}$ NMR (400 MHz, DMSO-d $) \delta$ (ppm) 7.57 $\left(3 \mathrm{H}, \mathrm{m}, \mathrm{H}-3^{\prime}, \mathrm{H}-4^{\prime}, \mathrm{H}-5^{\prime}\right), 8.00$ (4H, m, H-2"' $\mathrm{H}^{\prime \prime}$, H-5', H-6"'), 8.50 (1H, t, J = $8.0 \mathrm{~Hz}, \mathrm{H}-$ $\left.4^{\prime \prime}\right), 8.88\left(2 \mathrm{H}, \mathrm{A}, J=6.0 \mathrm{~Hz}, \mathrm{H}-2^{\prime}, \mathrm{H}-6{ }^{\prime}\right), 8.93$ (1H, s, H-5). ${ }^{13} \mathrm{C}\left\{{ }^{1} \mathrm{H}\right\}$ NMR (100 MHz, DMSOd6) $\delta(\mathrm{ppm}) 78.6,114.9,123.1,126.7$ (2C), 127.1 (2C), 129.0 (2C), 129.9, 131.0, 142.5 (2C), 146.0, 150.1, 151.5, 153.6, 155.4. Anal. Calcd. for $\mathrm{C}_{18} \mathrm{H}_{12} \mathrm{~N}_{6} \mathrm{O}_{3}$ : C 60.00, H 3.36, N 23.32; found: C 59.82, H 3.39, N 23.20.

2-(5-Nitrofur-2-yl)-5-methyl-6-nitro-1,2,4-triazolo[1,5-a]pyrimidin-7-one (3m).

$2.02 \mathrm{ml}(0.016 \mathrm{~mol}, 1.23 \mathrm{eq}$.) of ethyl acetoacetate was added to a suspension of the $2.00 \mathrm{~g}$ (0.013 mol, 1 eq.) of 3-(fur-2-yl)-5-amino-1,2,4-triazole 1e in $10 \mathrm{ml}$ of glacial AcOH. The resulting mixture was stirred for $2.5 \mathrm{~h}$ at reflux $\left(130{ }^{\circ} \mathrm{C}\right.$ oil bath temperature). The reaction mixture was cooled to $25^{\circ} \mathrm{C}$, the obtained precipitate was filtered off, washed with $10 \mathrm{ml}$ of $i-\mathrm{PrOH}$, and air dried to give $2.16 \mathrm{~g}$ of 4 . This solidwas dissolved in $20 \mathrm{ml}$ of $94 \% \mathrm{H}_{2} \mathrm{SO}_{4}$ at $25{ }^{\circ} \mathrm{C} .1 .98 \mathrm{ml}(0.031 \mathrm{~mol})$ of $70 \% \mathrm{HNO}_{3}$ was added to a resulting solution, maintaining the temperature of the reaction mixture at $5-10^{\circ} \mathrm{C}$. The reaction mixture was stirred for 3 hours at $25^{\circ} \mathrm{C}$. The resulting mixture was poured into ice water. The solid product formed was collected by filtration and washed with $\mathrm{H}_{2} \mathrm{O}$. Yellow powder $(1.53 \mathrm{~g}$, yield 50\%), m.p. > 300 C. FT-IR (neat) $v_{\max }\left(\mathrm{cm}^{-1}\right): 1729(\mathrm{C}=\mathrm{O}), 1640\left(\mathrm{NO}_{2}\right), 1346\left(\mathrm{NO}_{2}\right), 1314$ $\left(\mathrm{NO}_{2}\right) .{ }^{1} \mathrm{H}$ NMR $\left(400 \mathrm{MHz}, \mathrm{DMSO}-d_{6}\right) \delta(\mathrm{ppm}) 2.58\left(3 \mathrm{H}, \mathrm{s}, \mathrm{CH}_{3}\right) 7.47(1 \mathrm{H}, \mathrm{d}, J=4.0 \mathrm{~Hz}, \mathrm{H}-$ 3), $7.75\left(1 \mathrm{H}, \mathrm{d}, J=4.0 \mathrm{~Hz}, \mathrm{H}-4^{\prime}\right) .{ }^{13} \mathrm{C}\left\{{ }^{1} \mathrm{H}\right\} \mathrm{NMR}\left(100 \mathrm{MHz}, \mathrm{DMSO}-d_{6}\right) \delta$ (ppm) 18.3, 114.4, $114.8,127.8,146.6,149.4,150.8,152.2,152.9$, 153.3. Anal. Calcd. for $\mathrm{C}_{10} \mathrm{H}_{6} \mathrm{~N}_{6} \mathrm{O}_{6} * 3 \mathrm{H}_{2} \mathrm{O}: \mathrm{C}$ 33.34, H 3.36, N 23.33; found: C 33.44, H 3.42, N 23.14.

2-(Fur-2-yl)-6-nitro-1,2,4-triazolo[1,5-a]pyrimidin-7-one sodium salt (3n).

$6.55 \mathrm{~g}$ (0.020 mol, 1 eq.) of pyridinium 2-(fur-2-yl)-6-nitro-1,2,4-triazolo[1,5-a]pyrimidin-7-one $3 \mathbf{i}$ was added to the solution of $1.28 \mathrm{~g}$ (0.032 mol, 1.6 eq.) of $\mathrm{NaOH}$ in $65 \mathrm{ml}$ $\mathrm{H}_{2} \mathrm{O}$. The resulting suspension was reflux for 10 minutes and cooled to $25^{\circ} \mathrm{C}$. The solid product formed was collected by filtration and recrystallized from $\mathrm{H}_{2} \mathrm{O}$. Yellow crystals (3.88 g, yield 60\%), m.p. 259-261 ${ }^{\circ} \mathrm{C}$. FT-IR (neat) $\nu_{\max }\left(\mathrm{cm}^{-1}\right): 3358\left(\mathrm{H}_{2} \mathrm{O}\right), 1661(\mathrm{C}=\mathrm{O}), 1539$ $\left(\mathrm{NO}_{2}\right), 1256\left(\mathrm{NO}_{2}\right) .{ }^{1} \mathrm{H}$ NMR $\left(400 \mathrm{MHz}, \mathrm{DMSO}-\mathrm{d}_{6}\right) \delta(\mathrm{ppm}) 6.66\left(1 \mathrm{H}, \mathrm{dd}, \mathrm{H}-4^{\prime}\right), 7.10(1 \mathrm{H}, \mathrm{d}$, H-3'), 7.83-7.89 (1H, br.m, H-5'), $9.01(1 \mathrm{H}, \mathrm{s}, \mathrm{H}-5) .{ }^{13} \mathrm{C}\left\{{ }^{1} \mathrm{H}\right\}$ NMR (100 MHz, DMSO-d $) \delta$ (ppm) 110.9, 111.9, 123.2, 144.5, 146.4, 150.9, 153.5, 155.6, 158.7. Anal. Calcd. for $\mathrm{C}_{9} \mathrm{H}_{4} \mathrm{~N}_{5} \mathrm{O}_{4} \mathrm{Na} \mathrm{H}_{2} \mathrm{O}$ : C $37.64 \mathrm{H} 2.11$ N 24.39; found: C 37.73 H 2.09 N 24.42.

2-(Fur-2-yl)-6-nitro-1,2,4-triazolo[1,5-a]pyrimidin-7-one ammonium salt (3o).

The mixture of1.00 g (0.0031 mol) of 2-(fur-2-yl)-6-nitro-1,2,4-triazolo[1,5-a]pyrimidin-7-one pyridinium $3 \mathbf{i}$ and $10 \mathrm{ml}$ of $25 \%$ ammonia aqueous solution was reflux for 1 
hour. The reaction mixture was cooled to $25^{\circ} \mathrm{C}$. The solid product formed was collected by filtration and washed with of $\mathrm{H}_{2} \mathrm{O}$. Gray powder $(0.49 \mathrm{~g}$, yield $60 \%)$, m.p. $>300{ }^{\circ} \mathrm{C}$. FTIR (neat) $v_{\max }\left(\mathrm{cm}^{-1}\right): 3181\left(\mathrm{NH}_{4}\right), 1667(\mathrm{C}=\mathrm{O}), 1536\left(\mathrm{NO}_{2}\right), 1250\left(\mathrm{NO}_{2}\right) .{ }^{1} \mathrm{H}$ NMR $(400 \mathrm{MHz}$, DMSO- $\left.d_{6}\right) \delta(\mathrm{ppm})$ 6.63-6.69 (1H, m, H-4'), 7.05-7.11 (1H, m, H-3'), $7.15\left(4 \mathrm{H}, \mathrm{t}, \mathrm{NH}_{4}\right), 7.86$ $\left(1 \mathrm{H}, \mathrm{s}, \mathrm{H}-5^{\prime}\right), 9.01(1 \mathrm{H}, \mathrm{s}, \mathrm{H}-5) .{ }^{13} \mathrm{C}\left\{{ }^{1} \mathrm{H}\right\}$ NMR (100 MHz, DMSO-d6) $\delta$ (ppm) 110.8, 111.9, $123.2,144.5,146.5,150.8,153.5,155.5,158.7$. Anal. Calcd. for $\mathrm{C}_{9} \mathrm{H}_{8} \mathrm{~N}_{6} \mathrm{O}: \mathrm{C} 40.91, \mathrm{H} 3.05, \mathrm{~N}$ 31.81; found: C 41.00, H 3.10, N 31.99.

2-(Fur-2-yl)-6-nitro-1,2,4-triazolo[1,5-a]pyrimidin-7-one morpholinic salt (3p).

A suspension of $0.67 \mathrm{~g}$ (0.0021 mol, 1 eq.) of 2-(fur-2-yl)-6-nitro-1,2,4-triazolo[1,5a]pyrimidin-7-one pyridinium $3 \mathbf{i}$ in $5 \mathrm{ml} \mathrm{H}_{2} \mathrm{O}$ was acidified with $37 \% \mathrm{HCl}$ to $\mathrm{pH} \sim 1$. The formed precipitate was collected by filtration, washed with of $\mathrm{H}_{2} \mathrm{O}$ and air dried. The resulting solid was suspended in $8 \mathrm{ml}$ of $\mathrm{H}_{2} \mathrm{O}$ and $0.18 \mathrm{ml}$ ( $0.0021 \mathrm{~mol}, 1$ eq.) of morpholine was added. The resulting mixture was heated until a clear solution was formed. The reaction mixture was cooled to $25^{\circ} \mathrm{C}$. The solid product formed was collected by filtration and washed with of EtOH. Yellow powder (0.35 g, yield 65\%), m.p. 204-205 ${ }^{\circ} \mathrm{C}$. FT-IR (neat) $V_{\max }\left(\mathrm{cm}^{-1}\right): 3408\left(\mathrm{NH}_{2}\right), 1670(\mathrm{C}=\mathrm{O}), 1534\left(\mathrm{NO}_{2}\right), 1244\left(\mathrm{NO}_{2}\right) .{ }^{1} \mathrm{H}$ NMR $(400 \mathrm{MHz}, \mathrm{DMSO}-$ d6) $\delta(\mathrm{ppm}) 3.13\left(4 \mathrm{H}, \mathrm{m}, 2 \mathrm{xC}_{2}\right), 3.75\left(4 \mathrm{H}, \mathrm{m}, 2 \mathrm{xC}_{2}\right), 6.63-6.69\left(1 \mathrm{H}, \mathrm{m}, \mathrm{H}-4^{\prime}\right), 7.05-7.11(1 \mathrm{H}$,

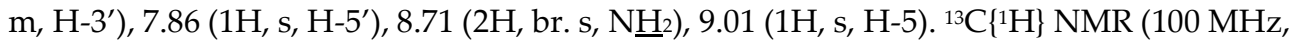
DMSO- $\left.d_{6}\right) \delta$ (ppm) 43.0, 63.3, 110.8, 111.9, 123.2, 144.4, 146.5, 150.7, 153.4, 155.4, 158.7. Anal. Calcd. for $\mathrm{C}_{13} \mathrm{H}_{14} \mathrm{~N}_{6} \mathrm{O}_{5}$ : C 46.71, H 4.22, N 25.14; found: C 46.95, H 4.11, N 25.30.

2-(Fur-2-yl)-6-nitro-1,2,4-triazolo[1,5-a]pyrimidin-7-one L-argininium salt (3q).

A suspension of $0.67 \mathrm{~g}$ (0.0021 mol, 1 eq.) of 2-(fur-2-yl)-6-nitro-1,2,4-triazolo[1,5a]pyrimidin-7-one pyridinium $3 \mathbf{i}$ in $5 \mathrm{ml} \mathrm{H}_{2} \mathrm{O}$ was acidified with $37 \% \mathrm{HCl}$ to $\mathrm{pH} \sim 1$.The formed precipitate was collected by filtration, washed with of $\mathrm{H}_{2} \mathrm{O}$ and air dried. The resulting solid was added to the solution $0.36 \mathrm{~g}$ ( $0.0021 \mathrm{~mol}, 1$ eq.) $L$-arginine in $5 \mathrm{ml}$ of $\mathrm{H}_{2} \mathrm{O}$. The resulting mixture was heated until a clear solution was formed. The reaction mixture was cooled to $25^{\circ} \mathrm{C}$. The solid product was collected by filtration and washed with EtOH. Yellow powder $\left(0.57 \mathrm{~g}\right.$, yield 65\%), m.p. 229-230 ${ }^{\circ} \mathrm{C}$. FT-IR (neat) $v_{\max }\left(\mathrm{cm}^{-1}\right): 3107\left(\mathrm{NH}_{2}\right)$, $1664(\mathrm{C}=\mathrm{O}), 1619(\mathrm{C}=\mathrm{O}), 1534\left(\mathrm{NO}_{2}\right), 1247\left(\mathrm{NO}_{2}\right) .{ }^{1} \mathrm{H}$ NMR $\left(400 \mathrm{MHz}, \mathrm{DMSO}-d_{6}\right) \delta(\mathrm{ppm})$ 1.46-1.71 (4H, br. m, 2xCH 2$), 1.70-1.83(1 \mathrm{H}$, br.m, $\mathrm{CH}), 3.10\left(2 \mathrm{H}, \mathrm{br} . \mathrm{m}, \mathrm{CH}_{2}\right), 3.34(2 \mathrm{H}$, br $\left.. \mathrm{m}, \mathrm{N}_{2}\right), 6.62-6.70\left(1 \mathrm{H}, \mathrm{m}, \mathrm{H}-4^{\prime}\right), 7.07\left(1 \mathrm{H}, \mathrm{d}, J=3 . \mathrm{Hz}, \mathrm{H}-3^{\prime}\right), 7.53\left(5 \mathrm{H}, \mathrm{br} . \mathrm{s}, \mathrm{N} \underline{\mathrm{H}}, 2 \mathrm{xN}_{2}\right)$, $7.86\left(1 \mathrm{H}, \mathrm{s}, \mathrm{H}-5^{\prime}\right), 9.00(1 \mathrm{H}, \mathrm{s}, \mathrm{H}-5) .{ }^{13} \mathrm{C}\left\{{ }^{1} \mathrm{H}\right\}$ NMR (100 MHz, DMSO-d 6 ) $\delta$ (ppm) 24.8, 28.2, 53.6, 110.7, 111.9, 123.2, 144.4, 146.5, 150.7, 153.4, 155.4, 157.2, 158.7, 172.42. Anal. Calcd. for $\mathrm{C}_{15} \mathrm{H}_{19} \mathrm{~N}_{9} \mathrm{O}_{6}$ : C 42.76, H 4.54, N 29.92; found: C 42.90, H 4.33, N 29.99.

General procedure for the synthesis of 3-R-[1,3,4] thiadiazolo[3,2-a]purin-9(3H)-one (6a-c).

Fe dust $(0.1 \mathrm{~mol}, 10$ eq.) was added to a stirred solution of the corresponding 5-alkylamino-6-nitro-[1,3,4] thiadiazolo[3,2-a]pyrimidin-7-one (0.01 mol, 1 eq.) 5a-c in a mixture of $45 \mathrm{ml}$ of glacial $\mathrm{AcOH}$ and $45 \mathrm{ml}$ of triethyl orthoformate. The mixture was stirred at reflux $\left(145^{\circ} \mathrm{C}\right.$ oil bath temperature) for 7 hours. The reaction mixture was cooled to $25^{\circ} \mathrm{C}$ and filtered. The filtrate was evaporated to dryness at $45^{\circ} \mathrm{C}$ in a vacuum and $100 \mathrm{ml}$ of $\mathrm{H}_{2} \mathrm{O}$ was added to the residue. The precipitate formed was filtered off and air dried.

3-(4-Hydroxyphenylethyl)-[1,3,4] thiadiazolo[3,2-a]purin-8-one (6a).

Yellow powder $(2.50 \mathrm{~g}$, yield $80 \%)$, m.p. $234-235{ }^{\circ} \mathrm{C}$. FT-IR (neat) $v_{\max }\left(\mathrm{cm}^{-1}\right): 3100$, 2743, 1689, 1504, 1376, 1281. ${ }^{1} \mathrm{H}$ NMR (400 MHz, DMSO-d $) \delta(\mathrm{ppm}) 3.00(2 \mathrm{H}, \mathrm{t}, J=7.2 \mathrm{~Hz}$, $\left.\mathrm{NCH}_{2} \underline{\mathrm{CH}}_{2}\right), 4.33\left(2 \mathrm{H}, \mathrm{t}, J=7.2 \mathrm{~Hz}, \mathrm{NCH}_{2} \mathrm{CH}_{2}\right), 6.62\left(2 \mathrm{H}, \mathrm{d}, J=8.0 \mathrm{~Hz}, \mathrm{H}-3^{\prime}, \mathrm{H}-5^{\prime}\right), 6.91(2 \mathrm{H}$, $\left.\mathrm{d}, J=8.0 \mathrm{~Hz}, \mathrm{H}-2^{\prime}, \mathrm{H}-66^{\prime}\right), 7.80(1 \mathrm{H}, \mathrm{s}, \mathrm{H}-6), 9.23(1 \mathrm{H}, \mathrm{s}, \mathrm{H}-2), 11.77(1 \mathrm{H}, \mathrm{s}, \mathrm{OH}) .{ }^{13} \mathrm{C}\left\{{ }^{1} \mathrm{H}\right\} \mathrm{NMR}$ $\left(100 \mathrm{MHz}, \mathrm{DMSO}-d_{6}\right) \delta$ (ppm) 34.4, 45.0, 115.2 (2C), 119.8, 127.7, 129.6 (2C), 140.9, 147.1, 147.9, 152.2, 156.0, 157.7. Anal. Calcd. for $\mathrm{C}_{14} \mathrm{H}_{11} \mathrm{~N}_{5} \mathrm{O}_{2} \mathrm{~S}$ : C 53.67, H 3.54, N 22.35; found: C 53.65, H 3.61, N 22.22.

3-(Cyclopropyl)-[1,3,4]thiadiazolo[3,2-a]purin-8-one (6b).

White powder $(2.50 \mathrm{~g}$, yield $80 \%)$, m.p. $272-274{ }^{\circ} \mathrm{C}$. FT-IR (neat) $v_{\max }\left(\mathrm{cm}^{-1}\right): 3077,1709$, 1531, 1488, 1315, 1233. ${ }^{1} \mathrm{H}$ NMR (400 MHz, DMSO-d6) $\delta(\mathrm{ppm}) 1.13(4 \mathrm{H}, \mathrm{d}, J=4.0 \mathrm{~Hz}$, 
$\left.\left(\underline{\mathrm{C}}_{2}\right)_{2}\right), 3.45-3.51(1 \mathrm{H}, \mathrm{m}, \mathrm{NC} \underline{\mathrm{H}}), 8.00(1 \mathrm{H}, \mathrm{s}, \mathrm{H}-6), 9.24(1 \mathrm{H}, \mathrm{s}, \mathrm{H}-2) .{ }^{13} \mathrm{C}\left\{{ }^{1} \mathrm{H}\right\} \mathrm{NMR}(100$ $\left.\mathrm{MHz}, \mathrm{DMSO}-d_{6}\right) \delta(\mathrm{ppm}) 5.4,25.3,120.0,140.5,146.7,149.0,151.9,157.4$. Anal. Calcd. for $\mathrm{C}_{9} \mathrm{H}_{7} \mathrm{~N}_{5} \mathrm{OS}: \mathrm{C} 46.34, \mathrm{H} 3.03, \mathrm{~N} 30.03$; found: C 46.29, H 2.98, N 30.19.

5-[4-(Diethoxymethyloxy)butyl] thiadiazolo[3,2-a]purin-8-one (6c).

White powder $\left(2.57 \mathrm{~g}\right.$, yield 70\%), m.p. 145-147 ${ }^{\circ} \mathrm{C}$. FT-IR (neat) $\nu_{\max }\left(\mathrm{cm}^{-1}\right): 3056,1705$, 1534, 1491, 1367, 1180. ${ }^{1} \mathrm{H}$ NMR (400 MHz, DMSO-d6) $\delta(\mathrm{ppm}) 1.08(6 \mathrm{H}, \mathrm{t}, J=8.0 \mathrm{~Hz}$, $\left.2 \mathrm{xC}_{3}\right), 1.46-1.52\left(2 \mathrm{H}, \mathrm{m}, \mathrm{C}_{2}\right), 1.83-1.89\left(2 \mathrm{H}, \mathrm{m}, \underline{\mathrm{CH}}_{2}\right), 3.43-3.49\left(6 \mathrm{H}, \mathrm{m}, 3 x \mathrm{OC}_{2}\right), 4.18$ $\left(2 \mathrm{H}, \mathrm{t}, J=8.0 \mathrm{~Hz}, \mathrm{NC} \underline{\mathrm{H}}_{2}\right), 5.10(1 \mathrm{H}, \mathrm{s}, \mathrm{OC} \underline{\mathrm{H}}), 8.16(1 \mathrm{H}, \mathrm{s}, \mathrm{H}-6), 9.26(1 \mathrm{H}, \mathrm{s}, \mathrm{H}-2) .{ }^{13} \mathrm{C}\left\{{ }^{1} \mathrm{H}\right\}$ NMR (100 MHz, DMSO-d6) $\delta$ (ppm) 14.9 (2C), 26.1, 26.4, 43.2, 58.9, 62.5, 111.9, 119.9, 140.9, 147.1, 148.0, 152.1, 157.6. Anal. Calcd. for $\mathrm{C}_{15} \mathrm{H}_{21} \mathrm{~N}_{5} \mathrm{O}_{4} \mathrm{~S}$ : C $49.03 \mathrm{H} 5.76$ N 19.06; found: C 49.04 H 5.70 N 19.00 .

3-Nitrobenz[4,5]imidazo[1,2-a]pyrimidin-4(1H)-one sodium salt (9).

$1.15 \mathrm{~g}$ (0.005 mol, 1 eq.) of 3-nitrobenz[4,5]imidazo[1,2-a]pyrimidin-4(1H)-one 8 was added to a stirred solution of the $0.20 \mathrm{~g}$ ( $0.005 \mathrm{~mol}, 1$ eq.) of $\mathrm{NaOH}$ in $20 \mathrm{ml}$ of $\mathrm{H}_{2} \mathrm{O}$. The resulting mixture was heated until a clear solution was formed. The reaction mixture was cooled to $25^{\circ} \mathrm{C}$. The solid product formed was collected by filtration and washed with EtOH. Yellow powder (1.01 g, yield 80\%), m.p. > $300{ }^{\circ} \mathrm{C}$. FT-IR (neat) $v_{\max }\left(\mathrm{cm}^{-1}\right): 3109$, 1692, 1611, 1547, 1450, 1297. ${ }^{1} \mathrm{H}$ NMR (400 MHz, DMSO-d6) $\delta(\mathrm{ppm}) 7.23(1 \mathrm{H}, \mathrm{d}, J=7.6 \mathrm{~Hz}$, H-7), $7.35(1 \mathrm{H}, \mathrm{t}, J=7.7 \mathrm{~Hz}, \mathrm{H}-8), 7.61(1 \mathrm{H}, \mathrm{t}, J=8.0 \mathrm{~Hz}, \mathrm{H}-6), 8.42(1 \mathrm{H}, \mathrm{t}, J=8.1 \mathrm{~Hz}, \mathrm{H}-9)$, 9.05 (1H, s, H-2). ${ }^{13} \mathrm{C}\left\{{ }^{1} \mathrm{H}\right\}$ NMR (100 MHz, DMSO-d6) $\delta$ (ppm) 115.2, 118.0, 120.8 120.9, 124.2, 129.8, 143.5, 154.2, 154.35, 154.43. Anal. Calcd. for $\mathrm{C}_{10} \mathrm{H}_{5} \mathrm{~N}_{4} \mathrm{NaO}_{3}: \mathrm{C} 47.63, \mathrm{H} 2.00, \mathrm{~N}$ 22.22; found: C 47.65, H 1.98, N 22.19.

General procedure for the synthesis of 2-(p-tolyl)-4-(R)-2H-benz[4,5]imidazo[1,2-a][1,2,3] triazolo[4,5-e]pyrimidines $(\mathbf{1 3 a - e , 1 4 a )}$.

To a stirred solution of $0.30 \mathrm{~g}(0.001 \mathrm{~mol}, 1 \mathrm{eq}$.$) of 2-( p$-tolyl)-2H-benz[4,5]imidazo[1,2a][1,2,3] triazolo[4,5-e]pyrimidine $\mathbf{1 0 a}, \mathbf{1 0 b}$ in $5 \mathrm{ml}$ of $\mathrm{CF}_{3} \mathrm{COOH} 0.001 \mathrm{~mol}$ (1 eq.) of the corresponding nucleophilic agent $\mathbf{N u H}$ was added. The resulting solution was stirred at $25^{\circ} \mathrm{C}$ for 5 hours. The reaction mixture was concentrated under reduced pressure and 10 $\mathrm{ml}$ of 1,4-dioxane was added to the residue and then a solution of $0.66 \mathrm{~g}(0.002 \mathrm{~mol})$ of $\mathrm{K}_{3}\left[\mathrm{Fe}(\mathrm{CN})_{6}\right]$ and $0.11 \mathrm{~g}$ (0.002 mol, 2 eq.) of $\mathrm{KOH}$ in $20 \mathrm{ml} \mathrm{H} \mathrm{H}_{2} \mathrm{O}$ was added. The resulting mixture was stirred for 5 hours at $25{ }^{\circ} \mathrm{C}$, extracted with $\mathrm{CHCl}_{3}(2 \times 20 \mathrm{ml})$, the combined organic layers was dried over anhydrous $\mathrm{Na}_{2} \mathrm{SO}_{4}$ and concentrated under reduced pressure. The residue was purified by column chromatography on silica gel 60 using $\mathrm{CHCl}_{3}$ as eluent to give the corresponding pure product.

2-(p-Tolyl)-4-(2,3,4-trimethoxyphenyl)-2H-benz[4,5]imidazo[1,2-a][1,2,3]triazolo[4,5-e]pyrimidine (13a).

Yellow powder $\left(0.27 \mathrm{~g}\right.$, yield 57\%), m.p. 226-228 ${ }^{\circ} \mathrm{C}$. FT-IR (neat) $v_{\max }\left(\mathrm{cm}^{-1}\right): 2935$, 1631, 1593, 1479, 1292, 1094. $\left.{ }^{1} \mathrm{H} \mathrm{NMR} \mathrm{(400} \mathrm{MHz,} \mathrm{CDCl} 3\right) \delta(\mathrm{ppm}) 2.44\left(3 \mathrm{H}, \mathrm{s}, \underline{\mathrm{C}}_{3}\right), 3.95$ $\left(3 \mathrm{H}, \mathrm{s}, \mathrm{OC} \underline{\mathrm{H}}_{3}\right), 3.99\left(3 \mathrm{H}, \mathrm{s}, \mathrm{OC} \underline{\mathrm{H}}_{3}\right), 4.13\left(3 \mathrm{H}, \mathrm{s}, \mathrm{OC} \underline{\mathrm{H}}_{3}\right), 6.89\left(1 \mathrm{H}, \mathrm{d}, J=8.8 \mathrm{~Hz}, \mathrm{H}-5^{\prime}\right), 7.34$ $\left(2 \mathrm{H}, \mathrm{d}, \mathrm{J}=8.3 \mathrm{~Hz}, \mathrm{H}-3^{\prime \prime}\right.$, H-5"'), 7.54-7.59 (2H, m, H-8, H-9), 7.74 (1H, d, J = 8.8 Hz, H-6'), 8.02-8.10 (1H, m, H-10), 8.18 (2H, d, J=8.2 Hz, H-2", $\left.\mathrm{H}-6^{\prime \prime}\right), 8.32-8.39(1 \mathrm{H}, \mathrm{m}, \mathrm{H}-7) .{ }^{13} \mathrm{C}\left\{{ }^{1} \mathrm{H}\right\}$ $\mathrm{NMR}\left(100 \mathrm{MHz}, \mathrm{CDCl}_{3}\right) \delta$ (ppm) 21.3, 56.3, 61.0, 62.4, 107.4, 113.2, 119.9 (2C), 120.9, 122.8, 124.0, 125.3, 126.9, 127.9, 130.3 (2C), 130.9, 137.5, 139.8, 142.7, 144.0, 145.8, 150.3 153.5, 156.2, 156.7. Anal. Calcd. for $\mathrm{C}_{26} \mathrm{H}_{22} \mathrm{~N}_{6} \mathrm{O}_{3}$ : C 66.94, $\mathrm{H} 4.75, \mathrm{~N} 18.02$; found: C 67.15, H 4.83, N 17.86.

2-(p-Tolyl)-4-(3,4-trimethoxyphenyl)-2H-benz[4,5]imidazo[1,2-a][1,2,3]triazolo[4,5-e]pyrimidine $(\mathbf{1 3 b})$.

Yellow powder $\left(0.27 \mathrm{~g}\right.$, yield 62\%), m.p. 257-259 ${ }^{\circ} \mathrm{C}$. FT-IR (neat) $v_{\max }\left(\mathrm{cm}^{-1}\right): 2933$, 1678, 1631, 1598, 1482, 1271. $\left.{ }^{1} \mathrm{H} \mathrm{NMR} \mathrm{(400} \mathrm{MHz,} \mathrm{CDCl}\right) \delta(p p m) 2.44\left(3 \mathrm{H}, \mathrm{s}, \underline{\mathrm{C}}_{3}\right), 3.97$ $\left(3 \mathrm{H}, \mathrm{s}, \mathrm{OC} \underline{\mathrm{H}}_{3}\right), 4.03\left(3 \mathrm{H}, \mathrm{s}, \mathrm{OC} \underline{\mathrm{H}}_{3}\right), 6.97\left(1 \mathrm{H}, \mathrm{d}, J=8.5 \mathrm{~Hz}, \mathrm{H}-5^{\prime}\right), 7.33(2 \mathrm{H}, \mathrm{d}, J=8.3 \mathrm{~Hz}, \mathrm{H}-$ 3", H-5'), 7.47-7.55 (2H, m, H-8, H-9), $7.98(1 \mathrm{H}, \mathrm{d}, J=7.7 \mathrm{~Hz}, \mathrm{H}-10), 8.16(2 \mathrm{H}, \mathrm{d}, J=8.0 \mathrm{~Hz}$, H-2" , H-6"'), 8.25 (1H, d, J = 7.6 Hz, H-7), 8.39 (1H, s, H-2'), 8.66 (1H, d, J = 8.4 Hz, H-2'). ${ }^{13} \mathrm{C}\left\{{ }^{1} \mathrm{H}\right\} \mathrm{NMR}\left(100 \mathrm{MHz}, \mathrm{CDCl}_{3}\right) \delta(\mathrm{ppm}) 21.3,56.08,56.14,110.6,111.0,113.0,119.5(2 \mathrm{C})$, $120.4,123.7,124.9,125.3,127.4,127.8,129.5,130.2$ (2C), 137.0, 139.8, 143.7, 146.9, 149.3, 
149.9, 153.1, 153.7. Anal. Calcd. for $\mathrm{C}_{25} \mathrm{H}_{20} \mathrm{~N}_{6} \mathrm{O}_{2}$ : C 68.80, H 4.62, N 19.25; found: C 68.96, $\mathrm{H}$ 4.63, N 19.12.

2-(p-Tolyl)-4-(thien-2-yl)-2H-benz[4,5]imidazo[1,2-a][1,2,3]triazolo[4,5-e]pyrimidine (13c).

Orange powder $(0.25 \mathrm{~g}$, yield $65 \%)$, m.p. $>300{ }^{\circ} \mathrm{C}$. FT-IR (neat) $v_{\max }\left(\mathrm{cm}^{-1}\right): 3045,1694$, 1628, 1539, 1407, 1344. ${ }^{1} \mathrm{H}$ NMR (400 MHz, $\left.\mathrm{CDCl}_{3}\right) \delta(\mathrm{ppm}) 2.48\left(3 \mathrm{H}, \mathrm{s}, \mathrm{C}_{3}\right), 7.31(1 \mathrm{H}, \mathrm{dd}$, $\left.J=5.0,3.8 \mathrm{~Hz}, \mathrm{H}-3^{\prime}\right), 7.39$ (2H, d, J = 8.2 Hz, H-3"', H-5' ), 7.50-7.58 (2H, m, H-8, H-9), 7.74 $\left(1 \mathrm{H}, \mathrm{dd}, J=5.0,1.2 \mathrm{~Hz}, \mathrm{H}-4^{\prime}\right), 7.99-8.04(1 \mathrm{H}, \mathrm{m}, \mathrm{H}-10), 8.25\left(2 \mathrm{H}, \mathrm{d}, J=8.4 \mathrm{~Hz}, \mathrm{H}-2^{\prime \prime}, \mathrm{H}-6^{\prime \prime}\right)$, 8.29-8.33 (1H, m, H-7), $8.77\left(1 \mathrm{H}, \mathrm{dd}, J=3.8,1.2 \mathrm{~Hz}, \mathrm{H}-2^{\prime}\right) .{ }^{13} \mathrm{C}\left\{{ }^{1} \mathrm{H}\right\}$ NMR $\left(100 \mathrm{MHz}, \mathrm{CDCl}_{3}\right)$ $\delta$ (ppm) 21.4, 113.0, 119.8 (2C), 120.8, 123.9, 125.4, 128.1, 128.6, 128.9, 130.3 (2C), 133.5, 134.0, 137.2, 140.0, 140.1, 144.1, 145.9, 149.7, 150.0. Anal. Calcd. for $\mathrm{C}_{21} \mathrm{H}_{14} \mathrm{~N}_{6} \mathrm{~S}$ : C $65.95, \mathrm{H}$ 3.69, N 21.97; found: C 65.86, H 3.63, N 22.05.

2-(p-Tolyl)-4-(1-Methyl-1H-pyrrol-2-yl)-2H-benz[4,5]imidazo[1,2-a][1,2,3]triazolo[4,5e]pyrimidine (13d).

Yellow powder $\left(0.22 \mathrm{~g}\right.$, yield 59\%), m.p. $>300{ }^{\circ} \mathrm{C}$. FT-IR (neat) $v_{\max }\left(\mathrm{cm}^{-1}\right): 3080,1626$, 1548, 1437, 1405, 1219. ${ }^{1} \mathrm{H}$ NMR $\left(400 \mathrm{MHz}, \mathrm{CDCl}_{3}\right) \delta(\mathrm{ppm}) 2.46\left(3 \mathrm{H}, \mathrm{s}, \mathrm{CH}_{3}\right), 4.36(3 \mathrm{H}, \mathrm{s}$, $\left.\mathrm{NC}_{3} 3\right), 6.36\left(1 \mathrm{H}, \mathrm{dd}, J=4.0,2.4 \mathrm{~Hz}, \mathrm{H}-4^{\prime}\right), 7,01\left(1 \mathrm{H}, \mathrm{d}, J=2.4 \mathrm{~Hz}, \mathrm{H}-3^{\prime}\right), 7.36(2 \mathrm{H}, \mathrm{d}, J=8.2$ Hz, H-3"' H-5'), 7.45-7.54 (2H, m, H-8, H-9), 7.94 (1H, d, J = 7.5 Hz, H-10), 8.08 (1H, d, J = $\left.1.7 \mathrm{~Hz}, \mathrm{H}-5^{\prime}\right), 8.21\left(2 \mathrm{H}, \mathrm{d}, J=8.5 \mathrm{~Hz}, \mathrm{H}-2^{\prime \prime}, \mathrm{H}-6^{\prime \prime}\right), 8.25(1 \mathrm{H}, \mathrm{d}, J=7.7 \mathrm{~Hz}, \mathrm{H}-7) .{ }^{13} \mathrm{C}\left\{{ }^{1} \mathrm{H}\right\} \mathrm{NMR}$ $\left(100 \mathrm{MHz} \mathrm{CDCl}_{3}\right) \delta(\mathrm{ppm}) 21.3,39.6,109.9,112.8,119.7$ (2C), 120.0, 122.2, 123.4, 125.2, $126.9,128.0,129.1,130.2$ (2C), 132.7, 137.3, 139.7, 143.5, 145.7, 148.0, 150.2. Anal. Calcd. for $\mathrm{C}_{22} \mathrm{H}_{17} \mathrm{~N}_{7}$ : C 69.64, H 4.52, N 25.84; found: C 69.53, H 4.59, N 25.76.

2-(p-Tolyl)-4-(1-naphthalene-2-ol)-2H-benz[4,5]imidazo[1,2-a][1,2,3]triazolo[4,5-e]pyrimidine $(\mathbf{1 3 e})$.

Orange powder $\left(0.29 \mathrm{~g}\right.$, yield 67\%), m.p. $>300 \circ$ C. FT-IR (neat) $v_{\max }\left(\mathrm{cm}^{-1}\right): 3041,2951$, 1623, 1433, 1339, 1274. ${ }^{1} \mathrm{H}$ NMR $\left(400 \mathrm{MHz}, \mathrm{CDCl}_{3}\right) \delta(\mathrm{ppm}) 2.35\left(3 \mathrm{H}, \mathrm{s}, \mathrm{CH}_{3}\right), 7.20-7.39(6 \mathrm{H}$, $\mathrm{m})$, 7.47-7.53 (2H, m, H-8, H-9), $7.77(1 \mathrm{H}, \mathrm{d}, J=6.9 \mathrm{~Hz}, \mathrm{H}-10), 7.88\left(1 \mathrm{H}, \mathrm{d}, J=9.0 \mathrm{~Hz}, \mathrm{H}-3^{\prime}\right)$, 7.92-8.00 (3H, m), 8.24-8.32 (1H, m, H-7), $11.79(1 \mathrm{H}, \mathrm{s}, \mathrm{OH}) .{ }^{13} \mathrm{C}\left\{{ }^{1} \mathrm{H}\right\} \mathrm{NMR}\left(100 \mathrm{MHz}, \mathrm{CDCl}_{3}\right)$ $\delta$ (ppm) 21.4, 112.3, 113.3, 119.8, 120.0 (2C), 120.8, 124.3, 124.4, 125.8, 126.2, 126.5, 128.0, 128.4, 129.1, 130.3, 130.4 (2C), 132.0, 135.1, 137.2, 140.3, 143.8, 146.2, 148.7, 158.7. Anal. Calcd. for $\mathrm{C}_{27} \mathrm{H}_{18} \mathrm{~N}_{6} \mathrm{O}$ : C 73.29, $\mathrm{H} 4.10, \mathrm{~N} 18.99$; found: C 73.35, H 4.16, N 18.82.

8,9-Difluor-2-(p-Tolyl)-4-(2,3,4-trimethoxyphenyl)-2H-benz[4,5]imidazo[1,2-a][1,2,3]triazolo[4,5-e]pyrimidine $(\mathbf{1 4 a})$.

Yellow powder $\left(0.32 \mathrm{~g}\right.$, yield 63\%), m.p. 270-272 ${ }^{\circ} \mathrm{C}$. FT-IR (neat) $v_{\max }\left(\mathrm{cm}^{-1}\right): 2947$, 1644, 1596, 1509, 1289, 1100. $\left.{ }^{1} \mathrm{H} \mathrm{NMR} \mathrm{(400} \mathrm{MHz,} \mathrm{CDCl}\right) \delta(p p m) 2.47\left(3 \mathrm{H}, \mathrm{s}, \mathrm{C}_{3}\right), 3.95$ $\left(3 \mathrm{H}, \mathrm{s}, \mathrm{OC} \underline{\mathrm{H}}_{3}\right), 4.00\left(3 \mathrm{H}, \mathrm{s}, \mathrm{OC} \underline{\mathrm{H}}_{3}\right), 4.13\left(3 \mathrm{H}, \mathrm{s}, \mathrm{OC} \underline{\mathrm{H}}_{3}\right), 6.89\left(1 \mathrm{H}, \mathrm{d}, J=8.7 \mathrm{~Hz}, \mathrm{H}-5^{\prime}\right), 7.38$ $\left(2 \mathrm{H}, \mathrm{d}, J=8.2 \mathrm{~Hz}, \mathrm{H}-3^{\prime \prime}, \mathrm{H}-5^{\prime \prime}\right), 7.76\left(1 \mathrm{H}, \mathrm{d}, J=8.7 \mathrm{~Hz}, \mathrm{H}-6^{\prime}\right), 7.87(1 \mathrm{H}, \mathrm{t}, J=8.7 \mathrm{~Hz}, \mathrm{H}-10)$, 8.15-8.24 (3H, m, H-7, H-2"', H-6"'). ${ }^{13} \mathrm{C}\left\{{ }^{1} \mathrm{H}\right\}$ NMR (100 MHz, $\left.\mathrm{CDCl}_{3}\right) \delta$ (ppm) 21.4, 56.3, 61.0, 62.3, $101.3(\mathrm{~d}, J=23.4 \mathrm{~Hz}), 107.4,108.3(\mathrm{~d}, J=20.4 \mathrm{~Hz}), 119.9(2 \mathrm{C}), 122.5,123.0(\mathrm{~d}, J=$ $11.2 \mathrm{~Hz}), 127.0,130.4(2 \mathrm{C}), 130.7,137.3,139.7$ (d, $J=11.2 \mathrm{~Hz}), 140.1,142.7,145.3,148.7$ (dd, $J=245.7,14.7 \mathrm{~Hz}), 149.8(\mathrm{dd}, J=243.0,12.6 \mathrm{~Hz}), 151.4,153.5,156.3,157.0$. Anal. Calcd. for $\mathrm{C}_{26} \mathrm{H}_{20} \mathrm{~F}_{2} \mathrm{~N}_{6} \mathrm{O}_{3}$ : C 62.15, $\mathrm{H} 4.01, \mathrm{~N}$ 16.73; found: C 62.27, H 4.16, N 16.59.

\subsection{Biology}

4.2.1. Animals

All animal procedures were carried out under the generally accepted ethical standards for the manipulations on animals adopted by the European Convention for the Protection of Vertebrate Animals used for Experimental and Other Scientific Purposes (1986) and taking into account the International Recommendations of the European Convention for the Protection of Vertebrate Animals used for Experimental research (1997). The study was approved by the Local Ethics Committee of the Volgograd State Medical University (registration No. IRB 00005839 IORG 0004900, OHRP), Certificate No. 2021/056, 15.06.2021. All sections of this study adhere to the ARRIVE Guidelines for reporting animal research [20]. The experiments were carried out on 10 male Chinchilla rabbits weighing $3.0-3.5 \mathrm{~kg}$ and 95 outbred albino male rats weighing 250-270 g. Animals were kept 
under standard vivarium conditions $\left(22-24{ }^{\circ} \mathrm{C}, 40-50 \%\right.$ humidity, ambient light) during the study.

\subsubsection{In vitro anticoagulant assay}

The study was performed on a platelet-poor plasma (PPP) stabilized with a $3.8 \%$ sodium citrate solution in a ratio of 9:1 according to the method [21]. Dabigatran etexilate (Boehringer Ingelheim Pharma GmbH and Co., Germany) was used as a reference drug. Test compounds and the reference drug were evaluated at a concentration of $100 \mu \mathrm{M}$. Effect on rabbit blood coagulogram in vitro was determined chronometrically with a SOLAR hemocoagulometer (Belarus) using commercial kits (Technology-Standard, Russia) as per manufacturer's instructions. The following parameters were determined: activated partial thromboplastin time, thrombin and prothrombin time. Hypercytokinemia conditions were modeled by incubation of whole blood with $S$. typhimurium LPS (Sigma, USA) at a final concentration of $20 \mathrm{ng} / \mathrm{ml}$ and subsequent preparation of PPP. Compounds that showed high dose-dependent prolongation of thrombin time without and under conditions of LPS-treatment were assessed for $\mathrm{IC}_{50}$ values using the regression analysis method in the Microsoft Excel 2007 program.

\subsubsection{Anticoagulant assay in animals}

The most active compounds were studied in vivo on male rats after a single intragastric administration in a volume of no more than $2 \mathrm{ml}$. Distilled water was used as a vehicle. In all experiments, control animals were injected with a vehicle in an equivalent volume.

The reference drug dabigatran etexilate was administered to rats 2 hours before the study at a $12 \mathrm{mg} / \mathrm{kg}$ dose (equivalent to the human dose, taking into account the interspecies conversion factor). The compounds were administered in doses equimolar to the dose of dabigatran etexilate and the efficacy was assessed after 1, 2 and 4 hours after administration. Depending on the activity, the doses of the compounds under study were increased by 2 and 4 times.

Blood was taken from the inferior vena cava of rats anesthetized with $400 \mathrm{mg} / \mathrm{kg}$ chloral hydrate intraperitoneally. To stabilize the blood, a 3.8\% aqueous solution of sodium citrate ( $\mathrm{pH}$ 6.0) was used in a ratio of 9:1. Coagulogram parameters of a plateletpoor plasma were measured with a SOLAR coagulometer according to the methods described above.

Also, the assessment of the parameters of hemostasis in rats was carried out by the method of thromboelastography [22]. The following parameters were measured: $R$ - time to formation of the first fibrin filaments; $K$ - time from $R$ until the clot reaches $20 \mathrm{~mm} ; \alpha$ Angle - the tangent of the curve made as the $K$ is reached; $M A$ - maximum amplitude characterizing the functional activity of platelets and clot strength.

\subsubsection{Statistical analysis}

Biological data were analyzed with 1-way ANOVA using Bonferroni's multiple comparison correction using the Microsoft Excel 2007 spreadsheet editor, STATISTICA 5.0 (StatSoft, Inc., USA) for Windows, and Prism 5.0 (GraphPad Inc.). The calculation of ED 50 (effective dose that prolongs thrombus formation time by $50 \%$ ) was performed using linear regression analysis.

\section{Conclusions}

A series of 23 novel azolo[1,5-a]pyrimidine derivatives and its condensed analogs were evaluated in vitro for anticoagulant properties. We have identified 5 active compounds that significantly prolong thrombin time out performing the reference drug dabigatran etexilate. Antithrombin activity of lead compounds was confirmed using LPStreated blood to mimic conditions of cytokine release syndrome. The studied compounds affected only the thrombin time value, reliably increasing it 6.5-15.2 times as compared to LPS-treated blood. IC 50 values were determined for the two most active compounds $3 a$ 
and $3 \mathrm{n}$ in the presence and in the absence of LPS. It was shown that the potency of compounds $3 a$ and $3 n$ exceeded dabigatran etexilate by 1.8 and 1.6 times, respectively, in normal blood and by 1.2 times after LPS-treatment. Lead compounds were also evaluated in animal experiments after a single intragastric administration to rats in doses equimolar to dabigatran etexilate. Compound 3a did not change the parameters of the coagulogram 4 hours after administration, while $3 \mathrm{n} 4$ hours after administration prolonged the thrombin time 1.4 times. Doubling the dose of compound 3 a also failed to show detectable anticoagulant effects in vivo. Two-time increased dose of compound $3 \mathrm{n}$ had an antithrombin effect increasing thrombin time by 3.3 times after 1, 2 and 4 hours, which is comparable to the activity of dabigatran etexilate. After administration of 4-times increased dose of compound $3 n$ we also observed an antithrombin effect comparable to the effect of dabigatran etexilate 1 hour after intragastric administration. All the data obtained were confirmed by thromboelastography that renders compound $3 \mathrm{n}$ as a promising anticoagulant agent. Compounds $3 \mathrm{n}, 3 \mathrm{~m}$ in animal experiments were inactive, compound $3 \mathrm{n}$ had a pronounced anticoagulant activity, but was inferior to the reference drug dabigatran etexilate.

Lead compounds were subjected to pharmacophore analysis by iterative neural network modeling. As a result, five types of QL-descriptors significantly affecting the level of FIIa-inhibitory activity were identified, which corresponds to neurons with Sens $\geq 1.1$ : $\{-\mathrm{N}=\ldots=\mathrm{O}\}$, Sens $=1.22 ; \quad\{-\mathrm{N}=\ldots$ CycAr06 $\}$, Sens $=1.27 ; \quad\{-\mathrm{N}=\ldots$ CycAr05 $\}$, Sens $=1.23 ;$ $\{-\mathrm{N}<\ldots=\mathrm{O}\}$,Sens $=1.10 ;\{-\mathrm{CH} 3 \ldots>\mathrm{C}(<)\}$,Sens $=1.10$. The combination of these binding points forms a pharmacophore that provides a high level of FIIa-inhibitory activity of the tested compounds. The identified pharmacophore is also present in the structure of dabigatran, and almost all of the found pharmacophore fragments occur in its molecule several times.

Supplementary Materials: NMR and IR Spectra of compounds 3, 6, 9, 13, 14.

Author Contributions: Synthesis, K.V.S. and V.V.F.; Iterative neural network pharmacophore analysis - P.M.V.; Studying of the anticoagulant activity - A.F.K., V.A.K., V.S.S., K.A.G., G.M.U.; methodology, V.L.R., S.K.K., A.A.S.; writing-original draft preparation, K.V.S., V.V.F., K.A.G., G.M.U.; writing-review and editing, A.F.K., P.M.V., V.A.K., V.S.S.; All authors have read and agreed to the published version of the manuscript."

Funding: This research was funded within the framework of the grant agreement as government subsidies from the Federal budget in accordance with paragraph 4 of article 78.1 of the Budget Code of the Russian Federation (Moscow, 1 October 2020, No. 075-15-2020-777).

Institutional Review Board Statement: All animal procedures were carried out under the generally accepted ethical standards for the manipulations on animals adopted by the European Convention for the Protection of Vertebrate Animals used for Experimental and Other Scientific Purposes (1986) and taking into account the International Recommendations of the European Convention for the Protection of Vertebrate Animals used for Experimental research (1997). The study was approved by the Local Ethics Committee of the Volgograd State Medical University (registration No. IRB 00005839 IORG 0004900, OHRP), Certificate No. 2021/056, 15.06.2021. All sections of this study adhere to the ARRIVE Guidelines for reporting animal research ${ }^{20}$.

Informed Consent Statement: Not applicable

Data Availability Statement: Data are contained within article

Acknowledgments: The team of authors would like to thank the Laboratory for Comprehensive Research and Expert Evaluation of Organic Materials under the direction of O. S. Eltsov.

Conflicts of Interest: The authors declare no conflict of interest.

Sample Availability: Samples of the compounds 3-14 are available from the authors. 


\section{References}

1. Mitchell, W.B. Thromboinflammation in COVID-19 Acute Lung Injury. Paediatr Respir Rev, 35 (2020) 20-24, doi:10.1016/j.prrv.2020.06.004.

2. Llitjos, J.-F.; Leclerc, M.; Chochois, C.; Monsallier, J.-M.; Ramakers, M.; Auvray, M.; Merouani, K. High Incidence of Venous Thromboembolic Events in Anticoagulated Severe COVID-19 Patients. J Thromb Haemost, 18 (2020) 1743-1746, doi:10.1111/jth.14869.

3. Klok, F.A.; Kruip, M.J.H.A.; van der Meer, N.J.M.; Arbous, M.S.; Gommers, D.; Kant, K.M.; Kaptein, F.H.J.; van Paassen, J.; Stals, M. a. M.; Huisman, M.V.; Endeman, H. Confirmation of the High Cumulative Incidence of Thrombotic Complications in Critically Ill ICU Patients with COVID-19: An Updated Analysis. Thromb Res, 191 (2020) 148-150, doi:10.1016/j.thromres.2020.04.041.

4. Lodigiani, C.; Iapichino, G.; Carenzo, L.; Cecconi, M.; Ferrazzi, P.; Sebastian, T.; Kucher, N.; Studt, J.-D.; Sacco, C.; Bertuzzi, A.; Sandrig, M.T.; Barco, S. Venous and Arterial Thromboembolic Complications in COVID-19 Patients Admitted to an Academic Hospital in Milan, Italy. Thromb Res, 191 (2020) 9-14, doi:10.1016/j.thromres.2020.04.024.

5. Tang, N.; Bai, H.; Chen, X.; Gong, J.; Li, D.; Sun, Z. Anticoagulant Treatment Is Associated with Decreased Mortality in Severe Coronavirus Disease 2019 Patients with Coagulopathy. J Thromb Haemost, 18 (2020) 1094-1099, doi:10.1111/jth.14817.

6. Testa, S.; Prandoni, P.; Paoletti, O.; Morandini, R.; Tala, M.; Dellanoce, C.; Giorgi-Pierfranceschi, M.; Betti, M.; Danzi, G.B.; Pan, A.; Palareti, G. Direct Oral Anticoagulant Plasma Levels' Striking Increase in Severe COVID-19 Respiratory Syndrome Patients Treated with Antiviral Agents: The Cremona Experience. J Thromb Haemost, 18 (2020) 1320-1323, doi:10.1111/jth.14871.

7. Savateev, K.V.; Ulomsky, E.N.; Butorin, I.I.; Charushin, V.N.; Rusinov, V.L.; Chupakhin, O.N. Azoloazines as A2a Receptor Antagonists. Structure-Activity Relationship. Russ. Chem. Rev., 87 (2018) 636-669, doi:10.1070/RCR4792.

8. Vassiliev, P.M.; Spasov, A.A.; Kosolapov, V.A.; Kucheryavenko, A.F.; Gurova, N.A.; Anisimova, V.A. Consensus Drug Design Using IT Microcosm. In Application of Computational Techniques in Pharmacy and Medicine; Gorb, L., Kuz'min, V., Muratov, E., Eds.; Challenges and Advances in Computational Chemistry and Physics; Springer Netherlands: Dordrecht, 2014; pp. 369-431 ISBN 978-94-017-9257-8.

9. Kůrková, V. Kolmogorov's Theorem and Multilayer Neural Networks. Neural Networks, 5 (1992) 501-506, doi:10.1016/08936080(92)90012-8.

10. Hilbe, J.M. Statistica 7. The American Statistician, 61 (2007) 91-94, doi:10.1198/000313007X172998.

11. Wu, C.; Lu, W.; Zhang, Y.; Zhang, G.; Shi, X.; Hisada, Y.; Grover, S.P.; Zhang, X.; Li, L.; Xiang, B.; Shi, J.; Li, X.-A.; Daugherty, A.; Smyth, S.S.; Kirchhofer, D.; Shiroishi, T.; Shao, F.; Mackman, N.; Wei, Y.; Li, Z. Inflammasome Activation Triggers Blood Clotting and Host Death through Pyroptosis. Immunity, 50 (2019) 1401-1411.e4, doi:10.1016/j.immuni.2019.04.003.

12. Pawlinski, R.; Pedersen, B.; Schabbauer, G.; Tencati, M.; Holscher, T.; Boisvert, W.; Andrade-Gordon, P.; Frank, R.D.; Mackman, N. Role of Tissue Factor and Protease-Activated Receptors in a Mouse Model of Endotoxemia. Blood, 103 (2004) 1342-1347, doi:10.1182/blood-2003-09-3051.

13. Zhang, H.; Zeng, L.; Xie, M.; Liu, J.; Zhou, B.; Wu, R.; Cao, L.; Kroemer, G.; Wang, H.; Billiar, T.R.; Zeh, H.J.; Kang, R.; Jiang, J.; Yu, Y.; Tang, D. TMEM173 Drives Lethal Coagulation in Sepsis. Cell Host Microbe, 27 (2020) 556-570.e6, doi:10.1016/j.chom.2020.02.004.

14. Yang, X.; Cheng, X.; Tang, Y.; Qiu, X.; Wang, Y.; Kang, H.; Wu, J.; Wang, Z.; Liu, Y.; Chen, F.; Xiao, X.; Mackman, N.; Billiar, T.R.; Han, J.; Lu, B. Bacterial Endotoxin Activates the Coagulation Cascade through Gasdermin D-Dependent Phosphatidylserine Exposure. Immunity, 51 (2019) 983-996.e6, doi:10.1016/j.immuni.2019.11.005.

15. Levi, M.; van der Poll, T. Coagulation and Sepsis. Thromb Res, 149 (2017) 38-44, doi:10.1016/j.thromres.2016.11.007.

16. Novinson, T.; Springer, R.H.; O’Brien, D.E.; Scholten, M.B.; Miller, J.P.; Robins, R.K. 2-(Alkylthio)-1,2,4-Triazolo[1,5-a]Pyrimidines as Adenosine Cyclic 3',5'-Monophosphate Phosphodiesterase Inhibitors with Potential as New Cardiovascular Agents. J Med Chem, 25 (1982) 420-426, doi:10.1021/jm00346a017.

17. Aghazadeh Tabrizi, M.; Baraldi, P.G.; Ruggiero, E.; Saponaro, G.; Baraldi, S.; Poli, G.; Tuccinardi, T.; Ravani, A.; Vincenzi, F.; Borea, P.A.; Varani, K. Synthesis and Structure Activity Relationship Investigation of Triazolo[1,5-a]Pyrimidines as CB2 Cannabinoid Receptor Inverse Agonists. Eur J Med Chem, 113 (2016) 11-27, doi:10.1016/j.ejmech.2016.02.032.

18. Fedotov, V.V.; Ulomskiy, E.N.; Gorbunov, E.B.; Eltsov, O.S.; Voinkov, E.K.; Savateev, K.V.; Drokin, R.A.; Kotovskaya, S.K.; Rusinov, V.L. 3-Nitropyrimido[1,2-a]Benzimidazol-4-Ones: Synthesis and Study of Alkylation Reaction. Chem Heterocycl Comp, 53 (2017) 582-588, doi:10.1007/s10593-017-2095-8.

19. Fedotov, V.V.; Ulomsky, E.N.; Belskaya, N.P.; Eltyshev, A.K.; Savateev, K.V.; Voinkov, E.K.; Lyapustin, D.N.; Rusinov, V.L. Benzimidazoazapurines: Design, Synthesis, and Photophysical Study. J. Org. Chem., 86 (2021) 8319-8332, doi:10.1021/acs.joc.1c00760.

20. Sert, N.P. du; Ahluwalia, A.; Alam, S.; Avey, M.T.; Baker, M.; Browne, W.J.; Clark, A.; Cuthill, I.C.; Dirnagl, U.; Emerson, M.; Garner, P.; Holgate, S.T.; Howells, D.W.; Karp, N.A.; Lazic, S.E.; Lidster, K.; MacCallum, C.J.; Macleod, M.; Pearl, E.J.; Petersen, O.H.; Rawle, F.; Reynolds, P.; Rooney, K.; Sena, E.S.; Silberberg, S.D.; Steckler, T.; Wurbel, H. Reporting Animal Research: Explanation and Elaboration for the ARRIVE Guidelines 2.0. PLOS Biology, 18 (2020) e3000411, doi:10.1371/journal.pbio.3000411.

21. Spasov, A.A.; Kucheryavenko, A.F.; Gaidukova, K.A.; Kosolapov, V.A.; Zhukovskaya, O.N. Antiplatelet Activity of New Derivatives of Benzimidazole Containing Sterically Hindered Phenolic Group in Their Structure. Research Results in Pharmacology, 6(1) (2020) 1-9, doi:10.3897/rrpharmacology.6.50373. 
22. Niemi, T.T.; Kuitunen, A.H. Artificial Colloids Impair Haemostasis. An in Vitro Study Using Thromboelastometry Coagulation Analysis. Acta Anaesthesiol Scand, 49 (2005) 373-378, doi:10.1111/j.1399-6576.2005.00619.x. 